\title{
New primary production in northwest European shelf seas, 1960-2003
}

\author{
Mike R. Heath ${ }^{1, *}$, Doug J. Beare ${ }^{2}$ \\ ${ }^{1}$ Fisheries Research Services (FRS) Marine Laboratory, 375 Victoria Road, Aberdeen AB11 9DB, UK \\ ${ }^{2}$ European Commission, Joint Research Centre (JRC), Institute for the Protection and Security of the Citizen (IPSC), Ispra, Italy
}

\begin{abstract}
Spatial and temporal patterns from 1960 to 2003 in annual potential new primary production (PNP) of the NW European shelf seas were derived from general additive models of nitrate concentrations and from data on riverine and atmospheric fluxes of oxidized nitrogen. Average PNP was highest in the seasonally stratified outer shelf regions $\left(>70 \mathrm{~g} \mathrm{C} \mathrm{m}^{-2} \mathrm{yr}^{-1}\right)$, where the proportion of PNP accounted for by vertical fluxes from deep water (>65\%) was correlated with the North Atlantic Oscillation (NAO) index. PNP was lowest in the central North Sea $\left(\sim 30 \mathrm{~g} \mathrm{C} \mathrm{m}^{-2} \mathrm{yr}^{-1}\right)$ and in the southern North Sea was correlated with river inputs that accounted for $24 \%$ of the annual total (average $\sim 50 \mathrm{~g} \mathrm{C} \mathrm{m}^{-2} \mathrm{yr}^{-1}$ ). Atmospheric deposition accounted for $\sim 3 \%$ of annual PNP region-wide, but in the northern North Sea this was higher than the contribution from rivers. Tidal fronts are traditionally considered to be highly productive zones, but we find them to have characteristically low PNP and conclude that they must be loci of high recycled production. The results indicate an exceptional flux of nitrate-rich ocean water onto the shelf in the early 1990s, which resulted in a pulse of PNP coincident with a well-documented 'regime shift' in the pelagic food web. North Sea-wide, long-term average PNP was approximately equal to production by all higher trophic levels combined, though trophic propagation of inter-annual variations was weakly defined. Nevertheless, there is a case for proposing that harvesting in areas and periods of low PNP should be managed more conservatively to minimize the risk of detrimental effects on the food web.
\end{abstract}

KEY WORDS: Nitrate $\cdot$ Primary production $\cdot$ Recycled production $\cdot f$-ratio $\cdot$ North Sea $\cdot$ Salinity Food web

\section{INTRODUCTION}

Photosynthetic fixation of carbon in the oceans requires corresponding uptakes of inorganic nutrient elements (nitrogen, phosphorus, silicon) and trace elements, such as iron and copper, from the seawater in, on average, stoichiometric proportions (Redfield et al. 1963). Carbon fixation is typically constrained by the concentration of nutrient or trace elements at times during the year; hence, the rate of supply, or flux, of the most limiting element to the photic zone should set a stoichiometric limit to annual primary production. In the case of nutrient limitation, annual total primary production can be apportioned into 2 components according to the source of limiting element. Production based on the uptake of nutrient regenerated from recently synthesized organic matter by excretion and microbial activity is referred to as 'recycled production'. In contrast, production derived from uptake of nutrient supplied to the photic zone by advection, convection, mixing, diffusion or atmospheric input is referred to as 'new production'. In seas where nitrogen is the main limiting nutrient element (Vitousek \& Howarth 1991), ammonia and urea represent the bulk of the recycled nutrient pool in the photic zone. Nitrate in the photic zone originates mainly from external sources and winter recharging of the photic zone, with a small and variable fraction produced in situ from recycled ammonia by nitrifying bacteria. Hence, many authors have taken the photosynthetic uptake of nitrate in the photic zone to be indicative of new production and the uptake of ammonia to be indicative of 
recycled production (Eppley \& Peterson 1979), though in fact, the uptake of any nitrate originating from in situ nitrification should also be regarded as contributing to recycled production (Yool et al. 2007). The ratio of nitrate uptake:total nitrogen uptake is typically referred to as the $f$-ratio (Dugdale \& Goering 1967).

Direct measurements of nitrate and ammonia uptake by phytoplankton, and nitrification rates by bacteria in the water column, require complicated short-term $(\leq 24 \mathrm{~h})$ incubations of sub-sampled water supplemented with isotope-labelled nutrient at a range of irradiances (Dugdale \& Goering 1967, Rees et al. 1995). These are inherently costly and can only be undertaken at a very limited number of sites. Extrapolating in space and time from a few such measurements to obtain realistic estimates of annual new production over an area such as the North Sea is then practically impossible. An alternative is to apply a proxy measure of annual uptake that can be generated from mass data sets. The most commonly used proxy is the depthintegrated mass of dissolved nitrate, which disappears from the photic zone during the spring bloom period. Assuming that there are no advective or diffusive inputs of nitrate to the photic zone during the bloom period and that there is no significant reliance on imported nitrate to support production outside this period, this loss term approximates the depth-integrated annual new production (Jennings et al. 1984). Conversion from production in terms of nitrogen units to production in terms of carbon units is then achieved by assuming that the 2 elements are stoichiometrically related according to the Redfield ratio ( $\mathrm{C}: \mathrm{N}$ molar ratio 106:16, Redfield et al. 1963). Support for this approach is provided by seasonal studies of the $f$-ratio in European shelf and inshore waters (e.g. Rees et al. 1995), which indicate values $>0.5$ between December and May (indicating dominance of nitrate uptake and new production), and $\leq 0.5$ between June and November (indicating dominance of ammonia uptake and recycled production).

In reality, combinations of advection, convection, turbulent mixing, and diffusion result in significant vertical fluxes of nitrate into the photic zone during the productive season, depending on particular circumstances. For example, in sub-tropical upwelling systems, episodic advective upwelling events replenish the nitrate in the photic zone from deep water, stimulating new production. In seasonally stratified temperate seas, vertical mixing equilibrates photic zone nitrate concentrations with deeper waters during the winter, whilst vertical diffusion across the seasonal thermocline is the main processes delivering nitrate from depth to the photic zone during the summer. Bisagni (2003) estimated annual potential new production (PNP, $\mu \mathrm{M} \mathrm{C} \mathrm{m}^{-2} \mathrm{yr}^{-1}$ ) in hydrographic provinces of the
Gulf of Maine from the 1-dimensional (vertical) equation:

$$
\mathrm{PNP}=\int_{t=1}^{t=365}\left[\frac{\mathrm{d}}{\mathrm{d} t} \int_{-z_{\mathrm{e}}}^{0} \mathrm{NO}_{3} \mathrm{~d} z-\left|K_{z, t} \frac{\partial \mathrm{NO}_{3}}{\mathrm{~d} z}\right|_{-z_{\mathrm{e}}}\right] \mathrm{d} t \times \mathrm{R}
$$

where $K_{z, t}$ is the vertical eddy diffusivity at the depth of the base of the photic zone $z_{\mathrm{e}}$ at time $t$ (days), $\mathrm{R}$ is the Redfield molar ratio of carbon:nitrogen (6.625) and $\partial \mathrm{NO}_{3} / \mathrm{dz}$ represents vertical gradient of nitrate concentration at depth $z_{\mathrm{e}}$. Bisagni (2003) discretised the temporal integration at $5 \mathrm{~d}$ intervals and based the calculations on interpolated observations of nitrate concentration and independently simulated values of vertical diffusivity.

Key to the success of the proxy approach is the availability of data on nitrate concentrations, sufficiently resolved in space and time to distinguish the pertinent features of variability. In recent years, satellite remote sensing data on sea surface chlorophyll and temperature have been used to calculate seasonal inventories of spatially resolved nitrate in the photic zone based on empirical relationships between nitrate, chlorophyll, temperature and time of year (e.g. Goes et al. 2000). However, whilst such empirical approaches may be feasible for open ocean waters, similar calculations for shelf seas are not so reliable, since allochthonous sources may lead to steep horizontal gradients of nutrient and light attenuation and the chlorophyll calibration of optical backscatter data is uncertain in shallow water due to high loads of suspended sediment and dissolved organic matter (Sathyendranath et al. 2001). On the other hand, archived data on direct measurements of nutrient concentration are more numerous for shelf waters than for ocean waters, so reasonable interpolations can perhaps be performed directly on nutrient measurement data.

Bisagni (2003) derived a climatological estimate of PNP using Eq. (1) for each of 5 hydrographic provinces in the Gulf of Maine based on archived nutrient data. There were 2 principal problems to be overcome. First, although archived multi-annual nutrient data were available for each province from a national database, the observations were highly heterogeneous in space and time. Bisagni (2003) used harmonic regression to fit a mean seasonal cycle of photic zone depth-integrated nitrate concentration within each province to the combined observations from many years, essentially assuming that each observation represented a random sample from the province and that there was no underlying inter-annual trend in the data. However, for some provinces the SD of residuals from the fitted seasonal cycles were of the same order as the seasonal amplitudes, implying a high degree of unresolved spatial and/or trend variability. Secondly, estimating the vertical eddy diffusivity for each province presented consid- 
erable difficulty, and Bisagni (2003) conducted a sensitivity analysis to assess the extent to which the calculated PNP was dependent on different assumptions about diffusivity. The outcome was that a relatively crudely derived constant value of diffusivity provided a closer fit to (admittedly sparse) direct measurements of primary production in shallow, well-mixed provinces, whilst a time series of model-derived estimates performed better in deeper stratified regions.

In this study, we focus on estimating new production from a combination of archived measurements of nitrate concentration collected throughout northwest European shelf waters between 1960 and 2003, and fluxes of nitrate from rivers and atmospheric deposition. Our aims in conducting the analysis were to reveal the spatial and temporal patterns in new production, and determine how these might be related to water column stratification, riverine inputs, atmospheric deposition, and processes at the shelf edge affecting the injection of nutrient onto the shelf from the ocean. Our purpose in pursuing these aims was to provide a basis for investigating the trophic control of spatial and temporal patterns in the production of higher trophic levels in the ecosystem, in particular zooplankton and fish.

Production of higher trophic levels has traditionally been considered to be a function of primary production and the efficiency of transfer between trophic levels. Frank et al. (2006) found a positive relationship between fishery yield and long-term average chlorophyll concentrations among 9 regions of the northwestern Atlantic. Similarly, Chassot et al. (2007) found a positive correlation between long-term average fishery yield and total annual primary production (TPP) derived from ocean-colour data among 14 regions of the northeastern Atlantic. However, Chassot et al. (2007) also showed that the ratio of primary production required to support fishery catches (PPR, as defined by Pauly \& Christensen 1995) to TPP varied by an order of magnitude ( 0.05 to 0.50$)$ between regions. In the context of our study, the transfer efficiency of TPP up the food web, and hence the fraction PPR/TPP, should be a function of the $f$-ratio (proportion of TPP based on recycling). Recycled primary production essentially reflects the metabolic requirements of the ecosystem, since it is based on excreta and within-season remineralisation of organic matter, whilst new production represents the potential for growth and reproduction of higher trophic levels (Horne et al. 1989). Hence, we hypothesize that in shelf seas, where the export of organic matter is small (compared to the surface layers of the open ocean, where sedimentation is a major flux), annual new primary production should equate closely to the combined production of all higher trophic levels. Thus, by considering new rather than total primary production as the basis for carbon and energy fluxes up the food web, we can perhaps circumvent potential spatial and temporal variability in the $f$-ratio and come closer to accounting for the mean production of higher trophic levels and the capacity of regional seas for harvesting.

\section{MATERIALS AND METHODS}

European shelf seas nitrate data. From the International Council for the Exploration of the Seas (ICES) Oceanographic Data Centre, we obtained data on nitrate concentrations $(\mu \mathrm{M})$ in the region $49^{\circ} \mathrm{N}, 12^{\circ} \mathrm{W}$ to $62^{\circ} \mathrm{N}, 10^{\circ} \mathrm{E}$ (Fig. 1) during the period 1 January 1960 to 31 December 2003. Each observation of nutrient concentration was accompanied by the day, month, year and depth of collection of the water sample on which the analysis was performed.

We used non-parametric regression models, also referred to as generalised additive models (GAM; Hastie \& Tibshirani 1990) to simultaneously smooth and interpolate the data as functions of both location (latitude and longitude) and time. We chose not to include depth explicitly as a predictor variable in the GAMs due to the additional computational overhead implied and the sparseness of depth resolution in the data. However, the system was clearly not homogeneous with respect to depth, so some form of vertical

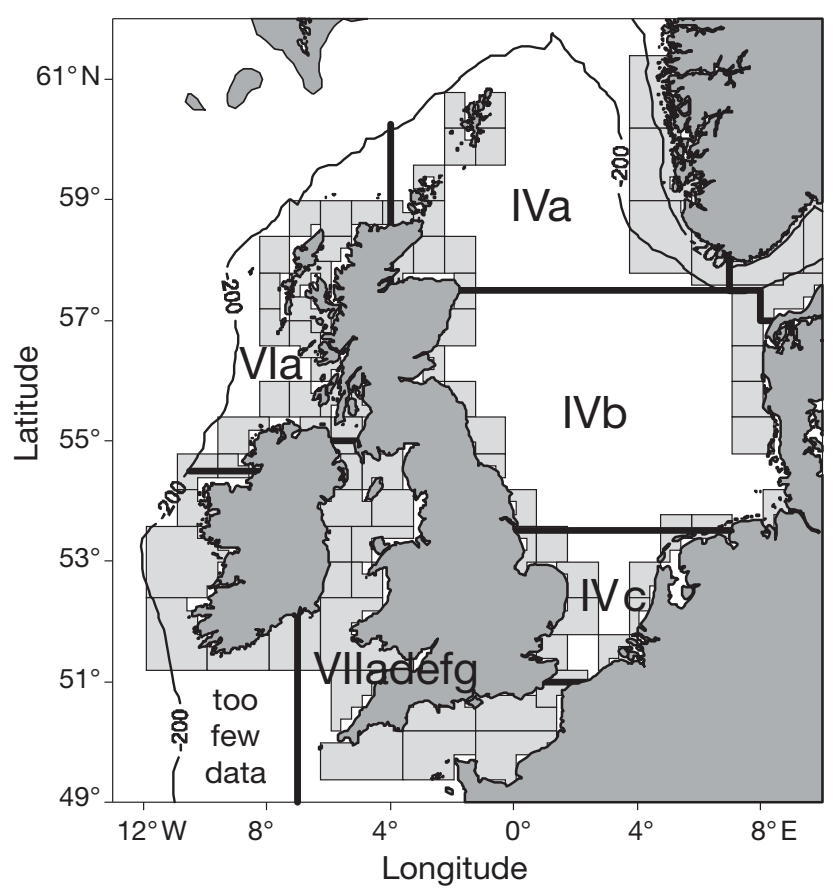

Fig. 1. Northwest European coastline and $200 \mathrm{~m}$ isobath that formed the inshore and offshore boundaries of the study domain, coastline segments for the assessment of riverine fluxes (denoted by light grey-shaded cells), and boundaries of the ICES fisheries assessment regions 
stratification of the analysis was required. We therefore divided the data into 2 sub-sets according to sample depth (shallower and deeper than $z_{\mathrm{s}}=30 \mathrm{~m}$ ) on the grounds that the seasonal thermocline depth $(\sim 30 \mathrm{~m})$ should divide the water column into 2 approximately homogeneous layers for much of the year and conducted separate analyses for each layer, treating each observation as a random sub-sample of the depthaveraged concentration. In addition, we restricted the analysis to locations with seabed depth $\left(z_{\text {seabed }}\right)$ shallower than $200 \mathrm{~m}$ to constrain the study within shelf waters. The GAMs were coded in the R-package ( $\mathrm{R}$ Development Core Team 2005) and we explored many smooth functions of various combinations of the predictor variables of location (latitude and longitude), time of year (month) and long-term trend (months since January 1960, i.e. 1 to 528) fitted to the naturallog transformed nitrate observations. Model selection is inherently difficult with GAMs, and it is typically the case that many different model formulations will produce a statistically adequate 'fit' to the data. A major consideration in designing an appropriate GAM function for this application was that the long-term trends could potentially interact with the spatial and seasonal effects, so the model function should be capable of accommodating the likelihood of different trends in nitrate concentration in different locations and seasons. The adequacy of different GAMs was assessed by examining the distribution of residuals and by comparing the modelled data to the raw observations.

Parameters from the fitted GAM models were used to predict synoptic gridded maps of layer-averaged nitrate concentration $\left(\mu \mathrm{M}_{i} \mathrm{sNO}_{3}=\right.$ depth averaged nitrate concentration in the surface layer, $\mathrm{bNO}_{3}$ for the bottom layer) at $1^{\circ}$ longitude $\times 0.5^{\circ}$ latitude horizontal intervals for the mid-point of each month throughout the period 1960 to 2004. From these, depth-integrated concentrations were calculated, i.e. $\left(\mathrm{sNO}_{3} \cdot z_{\mathrm{s}}\right)$ and $\left[\mathrm{bNO}_{3}\left(z_{\text {seabed }}-z_{\mathrm{s}}\right)\right]$, with seabed depth at each node being obtained by averaging the ETOPO5 5 min gridded elevation data set (National Geophysical Data Centre, www.ngdc.noaa.gov/mgg/global/global.html accessed 10 October 2007 ) within $1^{\circ}$ longitude $\times 0.5^{\circ}$ latitude cells centred on each node.

Hydrology and river nutrients. Nitrate inputs from rivers were extracted from published analyses (Heath 2007 and references therein, Radach \& Pätsch 2007 and references therein). The assembled data consisted of monthly (1960 to 2003) fluxes of oxidised inorganic nitrogen (nitrate + nitrite) $\left(\mathrm{kg} \mathrm{NOx-N} \mathrm{mo}{ }^{-1}\right)$ through 87 segments of coastline of average length approximately $75 \mathrm{~km}$ covering the European shelf (Fig. 1). Briefly, the methods used to derive these data involved the application of OSPAR principles for the study of riverine nutrient fluxes (OSPAR 1998) to data on land elevation, freshwater discharge rates and riverine nutrient concentrations, and their statistical interpolation by GAMs based on rainfall data to cover all years between 1960 and 2005.

Atmospheric deposition. Simulated data on the yearly integrated atmospheric deposition of total oxidized nitrogen (mg N m${ }^{-2} \mathrm{yr}^{-1}$ ) produced by the Cooperative Programme for Monitoring and Evaluation of the Long-range Transmission of Air pollutants in Europe (EMEP) unified $50 \times 50 \mathrm{~km}^{2}$ grid model (revision 1.7; Tarrasón 2003; www.emep.int/Model_data/ yearly_data.html; accessed 11 January 2008) were averaged over sub-regions of our study area. The EMEP $50 \times 50 \mathrm{~km}^{2}$ grid model represents the current state-of-the-art with respect to synthesis of data on emissions (natural and anthropogenic) to the atmosphere, and simulation of the chemical transformation of compounds, aerial dispersal and deposition. EMEP model data were available for the years 1980, 1985, 1990, 1995 and 2000.

Estimation of new primary production. Leaving aside for a moment the contribution of physical imports and exports of nitrate, we first assumed that annual PNP was represented by the mass of nitrate-nitrogen present in the surface (photic) layer at the start of the year, plus the mass flux into the surface layer from the bottom layer due to vertical diffusion and/or mixing. The vertical diffusion flux $\left(F_{\text {vertical }}, \mathrm{mmol} \mathrm{m}^{-2} \mathrm{yr}^{-1}\right)$ was estimated as the annual 'draw-down' of depth-integrated nitrate concentration in the bottom layer, i.e. the difference between annual maximum (between January and June) and minimum (between March and September):

$$
F_{\text {vertical }}=\left[\mathrm{bNO}_{3}\left(z_{\text {seabed }}-z_{\mathrm{s}}\right)\right]_{\max }-\left[\mathrm{bNO}_{3}\left(z_{\text {seabed }}-z_{\mathrm{s}}\right)\right]_{\min }
$$

whilst the total annual new primary uptake of nitrate ( $U_{\text {annual }}, \mathrm{mmol} \mathrm{m}^{-2} \mathrm{yr}^{-1}$ ) was the annual draw-down of total water column depth integrated nitrate:

$$
\begin{aligned}
U_{\text {annual }} & =\left\{\left(\mathrm{sNO}_{3} \cdot z_{\mathrm{s}}\right)+\left[\mathrm{bNO}_{3}\left(z_{\text {seabed }}-z_{\mathrm{s}}\right)\right]\right\}_{\text {max }} \\
& -\left\{\left(\mathrm{sNO}_{3} \cdot z_{\mathrm{s}}\right)+\left[\mathrm{bNO}_{3}\left(z_{\text {seabed }}-z_{\mathrm{s}}\right)\right]\right\}_{\text {min }}
\end{aligned}
$$

As did previous authors, we converted annual molar nitrate uptake or flux to potential new primary carbon molar production (mmol C m${ }^{-2} \mathrm{yr}^{-1}$ ) by application of the Redfield ratio $(\mathrm{R}=6.625)$, and to mass production (PNP, $\mathrm{mg} \mathrm{C} \mathrm{m}^{-2} \mathrm{yr}^{-1}$ ) by application of the appropriate molecular weight (12):

$$
\mathrm{PNP}=U_{\text {annual }} \cdot \mathrm{R} \cdot 12
$$

External imports or exports of nitrate should not invalidate our draw-down estimates of PNP if they occur during the period of the year when autotrophic uptake is negligible (winter). Imports or exports during this period merely contribute to the annual maximum (winter) concentration achieved and hence are implic- 
itly included in our draw-down estimate of PNP. However, imports (e.g. atmospheric deposition and river discharges) and exports (e.g. denitrification) during the spring and summer autotrophic uptake period will lead directly to under- or overestimation of PNP. To assess the additional contribution of such processes to annual PNP as estimated by the draw-down approach, we assumed that the autotrophic uptake period corresponded to the months March to September throughout the study area, integrated data on the rates of import and export over this period, and assumed that they contributed $100 \%$ to annual PNP.

European shelf seas salinity data. Salinity data from water bottle and CTD casts in the study area between January 1950 and December 2003 were obtained from the ICES Oceanographic Data Centre. The data were analysed in 2 ways. First, for each of 2 depth intervals (surface to $30 \mathrm{~m}$, and 30 to $200 \mathrm{~m}$ ) data from all years and selected months combined were bin-averaged (arithmetic mean) over $1^{\circ}$ longitude $\times 0.5^{\circ}$ latitude cells covering the study domain (Fig. 1), to produce a climatological overview of the distribution of salinity. Secondly, within particular sub-regions defined by latitude, longitude and depth intervals, data were averaged over calendar months for each successive year in the series 1959 through 2003 to produce spatially averaged time series.

Tidal stratification parameter. The $\mathrm{M}_{2}$ harmonic component of tidal current amplitudes at the seabed were estimated from output of a run of the Hamburg Shelf Ocean Model (HAMSOM; Backhaus \& Hainbucher 1987) with longitudinal grid resolution of $0.25^{\circ}$, latitudinal resolution $0.125^{\circ}$ degrees and 11 layers. The model run, carried out at the University of Hamburg, was configured with a homogeneous density field and forced only by tidal sea surface elevation $\left(\mathrm{M}_{2}\right.$ constituent) at the open boundaries taken from a global tidal model. After reaching a cyclo-stationary state, the hourly velocities and surface elevations during 2 simulated days were saved. Finally, the time series of velocities at each grid point were treated by a harmonic analysis in order to describe the tidal current in terms of phase and amplitude components. The SimpsonHunter stratification parameter (Simpson \& Hunter 1974) was then calculated as:

$$
\Phi=\log _{10}\left(\frac{z_{\text {seabed }}(\mathrm{m})}{\left(\text { tidal amplitude }\left(\mathrm{m} \mathrm{s}^{-1}\right)\right)^{3}}\right)
$$

Values of $\Phi \leq 1.6$ were taken to indicate a year-round tidally well-mixed water column, values between 1.6 and 2.4 to indicate summer frontal zones, and $\geq 2.4$ to indicate waters capable for summer stratification.

\section{RESULTS}

The data set obtained from the ICES Data Centre included 45561 observations of nitrate concentration in

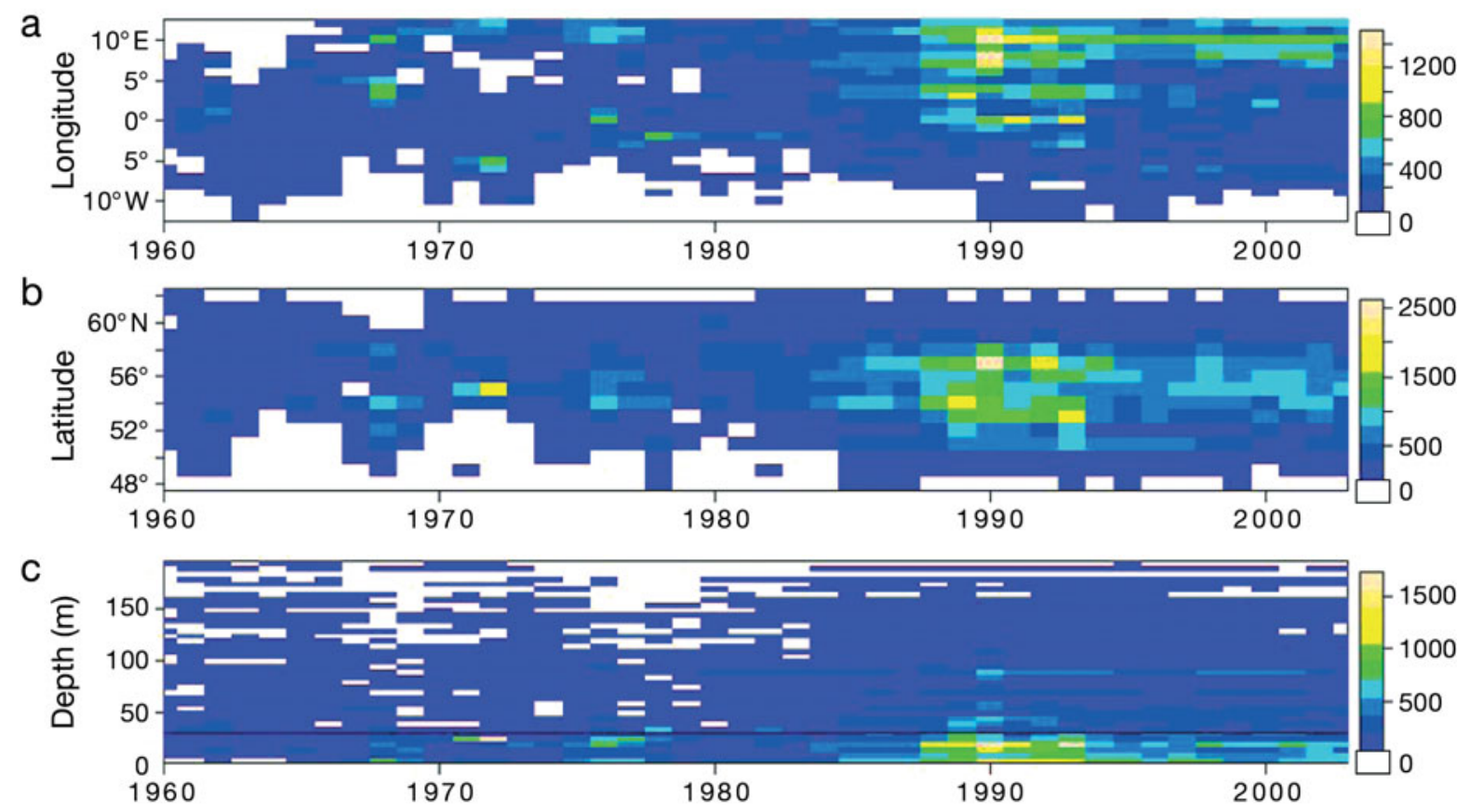

Fig. 2. Spatial, depth and temporal distributions of shelf sea nitrate measurements available from the ICES database for $1960-2003$. Numbers of samples were summed over intervals of (a) year and longitude, (b) year and latitude, or (c) year and depth. Colour scale indicates the number of samples in each interval, with white areas indicating an absence of samples 
the study area. However, the observations were heterogeneously distributed in horizontal space, depth, and time (Fig. 2). The data were particularly sparse in the southwestern corner of the domain, at least until after 1985. We therefore excluded an area west of $7^{\circ} \mathrm{W}$ and south of $54^{\circ} 30^{\prime} \mathrm{N}$ from the analysis. Following an exhaustive exploration of the data using a variety of GAM functions, we eventually chose a smoothing model of the following form for each depth layer based on the distribution of residuals around the fitted model:

$$
\begin{aligned}
& \log _{\mathrm{e}}(\text { nitrate })=\mathrm{s}(\text { month })+\mathrm{s}(\text { trend })+\mathrm{s}(\text { month, trend }) \\
& +\mathrm{s}(\text { lon,lat })+\mathrm{s}(\text { trend })+\mathrm{s}(\text { trend,month,lon,lat })+\text { error }
\end{aligned}
$$

where s refers to a smoothing function, in this case a LOESS (local-regression function; Cleveland et al. 1992) with a span of 0.05 . The trend terms in the models were represented by the numbers 1 to 528 (i.e. $12 \times$ 1960 to 2003), 'lon' and 'lat' refer to longitude and latitude, and the months (1 through 12) expressed the within-year seasonal structure in the data. For both depth layers, all the variables in the models described significant proportions of variability (Table 1) and the GAMs explained 88 and $69 \%$ of the variance in the surface and bottom layer nitrate data, respectively. The fitted GAMs were used to predict a dataset of monthly synoptic distributions of nitrate concentration $\left(\log _{\mathrm{e}} \mu \mathrm{M}\right)$ at $1^{\circ}$ longitude $\times 0.5^{\circ}$ latitude horizontal resolution for the 0 to $30 \mathrm{~m}$ and $30 \mathrm{~m}$ to seabed layers between January 1960 and December 2003. As examples, predictions for month of January in the years 1960, 1970, 1980, 1990 and 2000 are shown in Figs. 3 \& 4 .

Table 1. Summary of the generalised additive model fitted to the $\log _{\mathrm{e}}$ (nitrate concentrations) for depth range $0-30$ and $30 \mathrm{~m}$ to seabed depth. The significance level for each smoothing term was $<0.001$. Overall $\mathrm{r}^{2}$ (correlation between fitted values and raw values) $=88 \%$ for $0-30 \mathrm{~m}$ depth and $69 \%$ for $30 \mathrm{~m}$ to seabed depth. s: LOESS smooth function; lon: longitude; lat: latitude

\begin{tabular}{|lcccc|}
\hline & df & $\begin{array}{c}\text { Non parametric } \\
\text { df }\end{array}$ & $F$ & $\begin{array}{c}\text { Probability } \\
>F_{\text {critical }}\end{array}$ \\
\hline 0-30 m depth & & & & \\
Intercept & 1 & & & \\
s(month) & 1 & 4.1 & 4339.5 & $<2.2 \times 10^{-16}$ \\
s(trend) & 1 & 2.4 & 159.0 & $<2.2 \times 10^{-16}$ \\
s(lon,lat) & 2 & 38.1 & 579.4 & $<2.2 \times 10^{-16}$ \\
s(trend,month) & 2 & 10.1 & 1988.0 & $<2.2 \times 10^{-16}$ \\
s(lon,lat, trend, & 4 & 8.1 & 296.0 & $<2.2 \times 10^{-16}$ \\
$\quad$ month) & & & & \\
30 m-seabed depth & & & & \\
Intercept & 1 & 4.1 & 1086.58 & $<2.2 \times 10^{-16}$ \\
s(month) & 1 & 2.4 & 362.63 & $<2.2 \times 10^{-16}$ \\
s(trend) & 1 & 37.4 & 163.85 & $<2.2 \times 10^{-16}$ \\
s(lon,lat) & 2 & 10.4 & 394.82 & $<2.2 \times 10^{-16}$ \\
s(trend,month) & 2 & 83.4 & 109.45 & $<2.2 \times 10^{-16}$ \\
s(lon,lat,trend,month) & 4 & 4.1 & 1086.58 & $<2.2 \times 10^{-16}$ \\
& & & & \\
\hline
\end{tabular}

Annual maxima and minima of depth-integrated nitrate concentrations $\left(\mathrm{mmol} \mathrm{m}^{-2}\right)$ in the combined surface and bottom layers were located for each $1^{\circ}$ longitude $\times 0.5^{\circ}$ latitude grid node in the GAM-predicted monthly synoptic dataset, as the basis for estimating the vertical flux of nitrate and annual PNP (Eqs. 2-4). The resulting estimates of shelf-wide spatial distributions of annual PNP are shown for a sub-set of years in Fig. 5. The central North Sea, especially the shallow Dogger Bank region, and the inner parts of the west of Scotland shelf were consistently associated with minimum annual PNP (less than $20 \mathrm{~g} \mathrm{C} \mathrm{m}^{-2} \mathrm{yr}^{-1}$ ). Higher values (>100 $\mathrm{g} \mathrm{C} \mathrm{m}^{-2} \mathrm{yr}^{-1}$ ) were found along the continental European coast of the North Sea, in the northern North Sea, outer shelf west of Scotland, and in the Irish Sea and English Channel.

To estimate the long-term changes in PNP, the annual data were averaged over the ICES fisheries assessment regions: northern North Sea (ICES region IVa), central North Sea (ICES Region IVb), southern North Sea (ICES Region IVC), west of Scotland (ICES Region VIa), and the southwest UK, including the Irish Sea, Bristol Channel and English Channel (ICES Regions VIIa, VIId, VIIe, VIIf, VIIg east of $7^{\circ} \mathrm{W}$ combined, hereafter referred to as Area VII) (Fig. 1). Longterm average PNP in the domain as a whole (Fig. 6) was $56.5 \pm 5.6 \mathrm{~g} \mathrm{C} \mathrm{m}^{-2} \mathrm{yr}^{-1}$ (mean $\pm \mathrm{SD}$ ). Sub-domain long-term averages were higher than the domain as a whole in the northern regions (VIa and IVa) and lower in the central and southern North Sea (Table 2). Subregion VII to the southwest of the UK showed a similar long-term average PNP to the domain as a whole $\left(60.1 \mathrm{gC} \mathrm{m}^{-2} \mathrm{yr}^{-1}\right)$, but with a large $\mathrm{SD}\left( \pm 21.2 \mathrm{~g} \mathrm{C} \mathrm{m}^{-2} \mathrm{yr}^{-1}\right)$ caused by the combination of an underlying increasing trend and a large pulse of PNP during the period 1990 to 1995 . This pulse was evident also in Region VIa to the west of Scotland and in the domain as a whole, but not in the North Sea. The principal cause of the PNP pulse was an enhancement of winter nitrate levels, especially in the sub-photic zone (>30 m) beginning in 1991 and extending though to 1995 (Fig. 4).

The climatological spatial distribution of winter (November to March) salinity (Fig. 7) showed that high-salinity ocean water encroached onto the shelf in both the upper and lower layers in 3 main regions: southwest of the UK (southern part of Region VII), northern North Sea (Region IVa), and to a lesser extent the west of Scotland (Region VIa). We defined a $200 \mathrm{~km}$ wide strip along the outer shelf bounded on the offshore side by the $200 \mathrm{~m}$ isobath, and 
a January
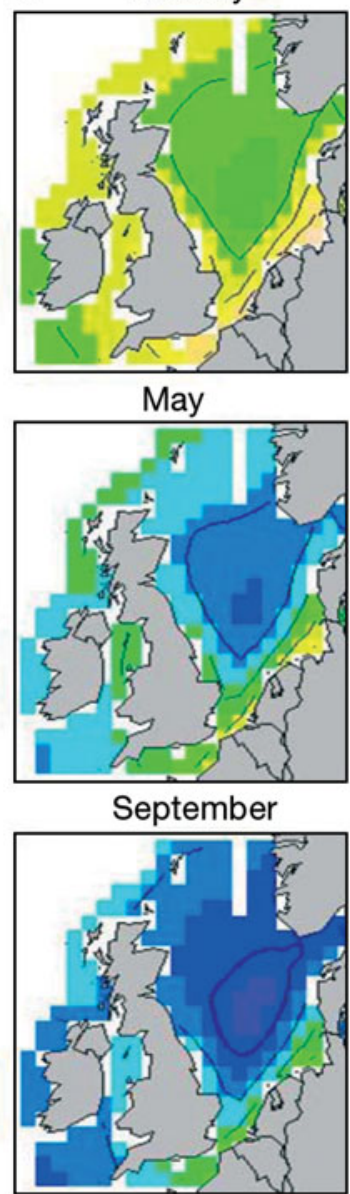

b

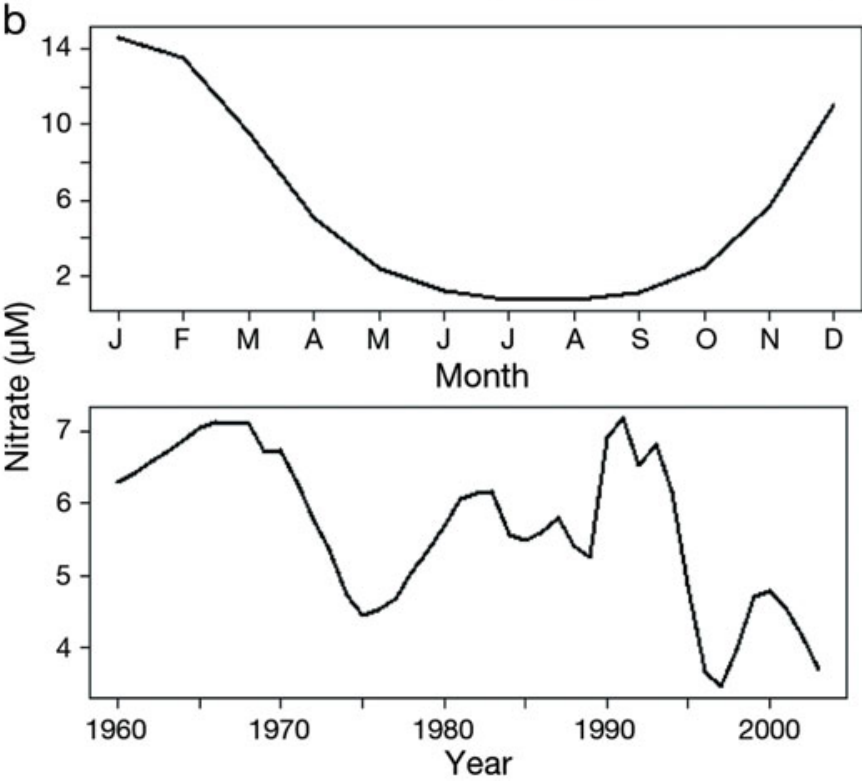

February

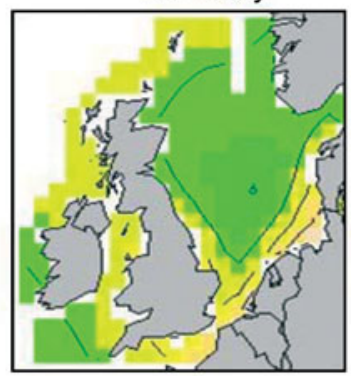

June

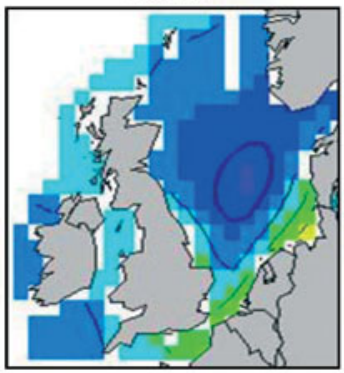

October

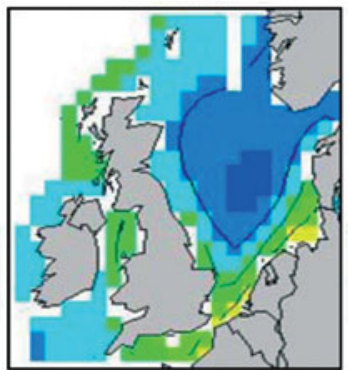

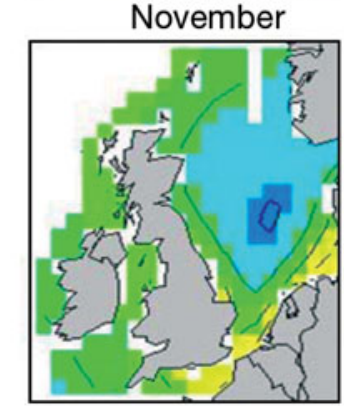

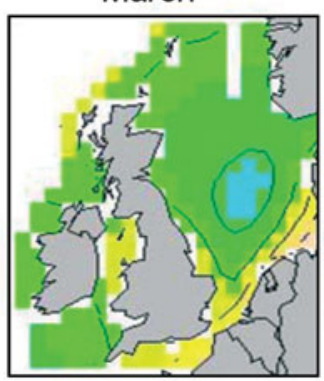

July
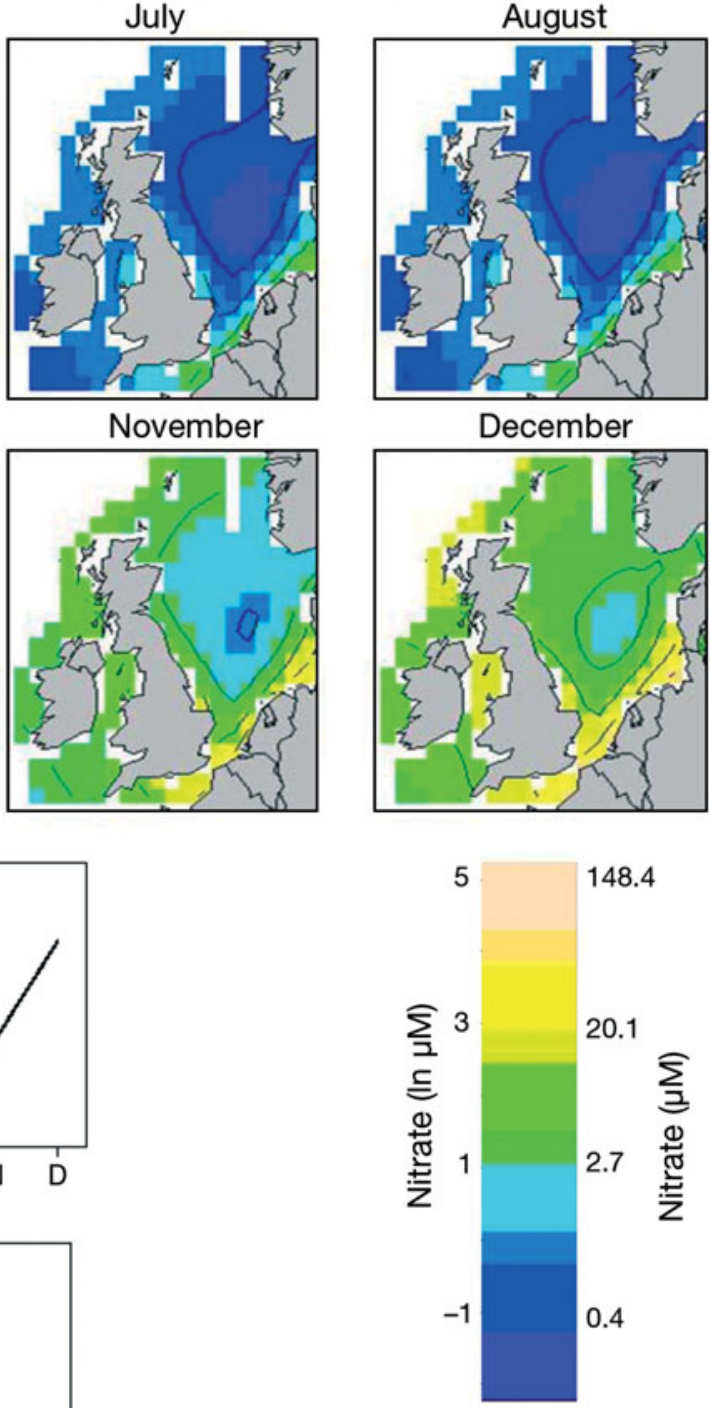

Fig. 3. Summary of generalised additive model-fitted distributions of nitrate concentration $(\mu M)$ in the surface layer $(0-30 \mathrm{~m})$. (a) Spatial maps show the distributions of $\log _{\mathrm{e}}$-transformed concentrations $(\ln \mu \mathrm{M})$ at mid-month intervals during an example year (1995). Contours shown at log-nitrate values of $-1,0,1,2,3$ and 4 . (b) Line plots show, upper: spatially and temporally averaged (1960-2003) seasonal pattern of monthly concentrations; lower: spatially and temporally averaged long-term trend (1960-2003) in concentrations 
a January

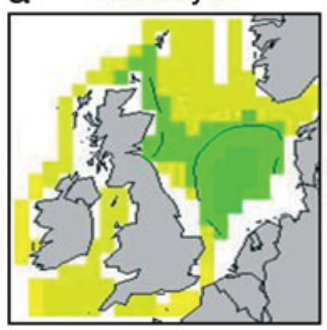

May

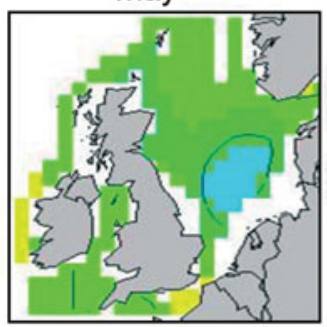

September

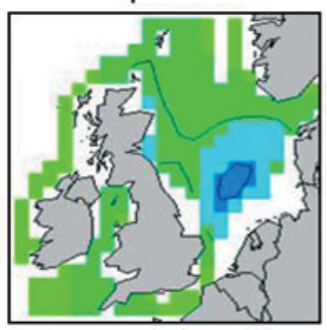

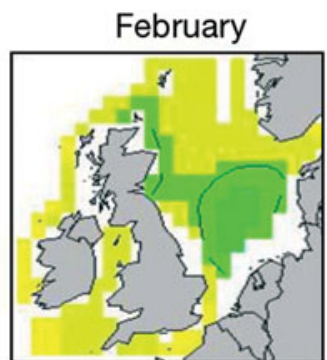

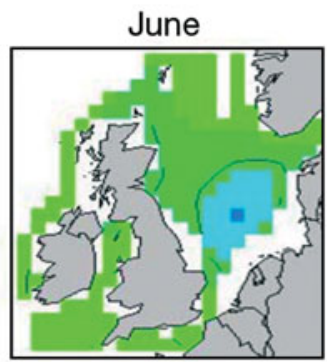

October

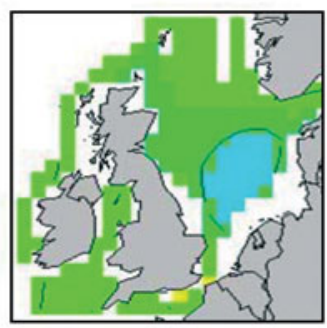

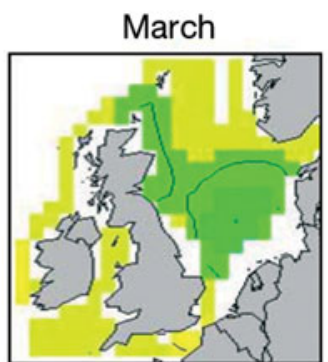

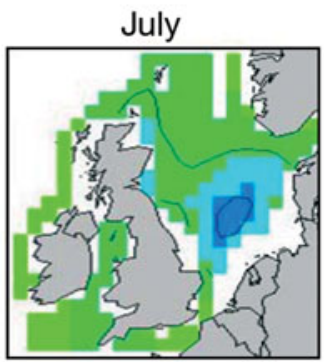

November

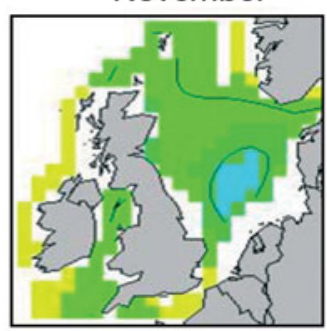

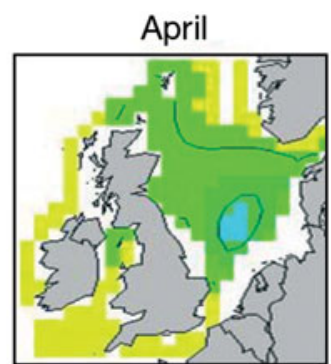
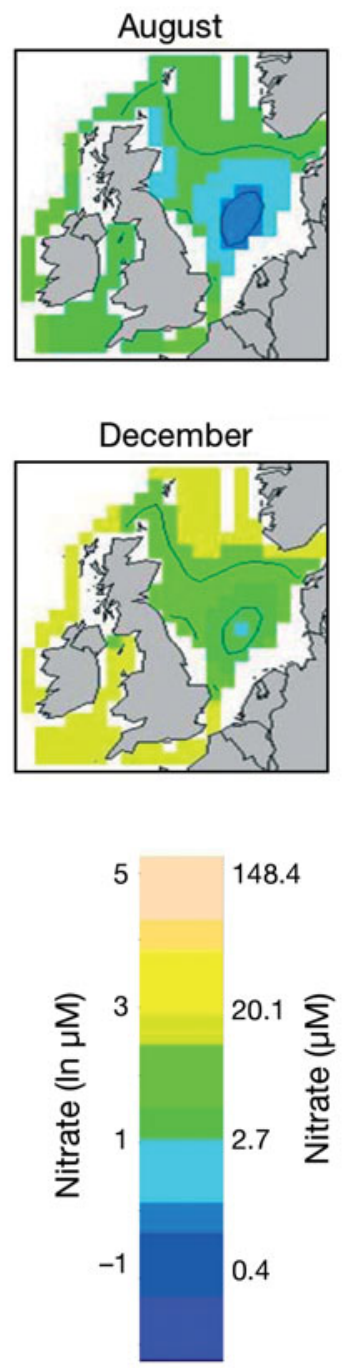

b

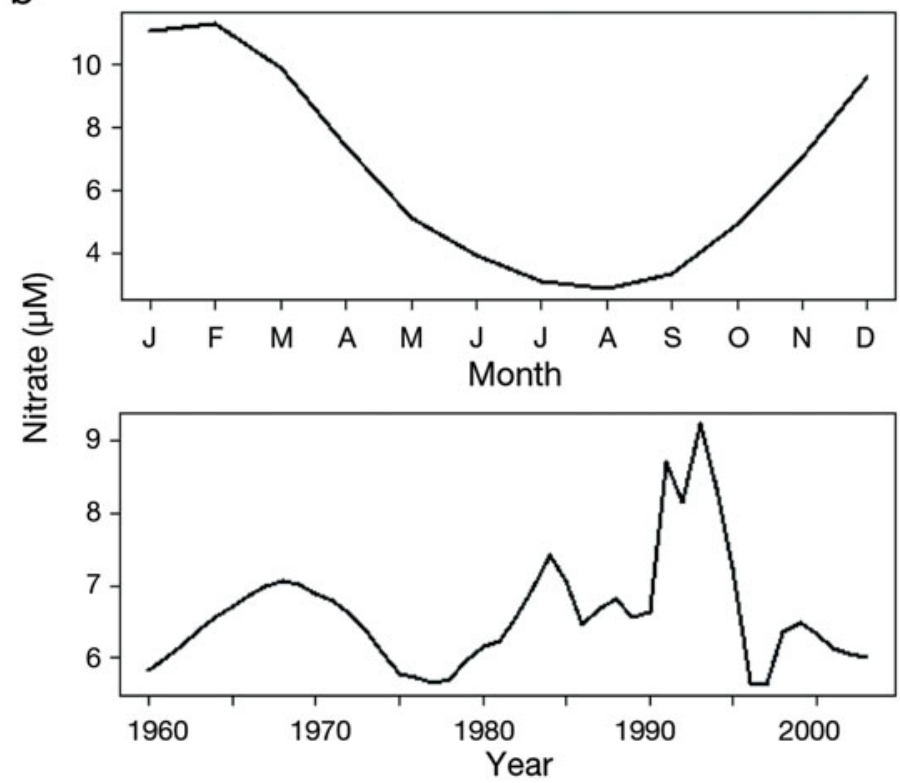

Fig. 4. Summary of generalised additive model-fitted distributions of nitrate concentration $(\mu \mathrm{M})$ in the deep layer (30 m-seabed or maximum of $200 \mathrm{~m}$ ). (a) Spatial maps show the distributions of $\log _{\mathrm{e}}$-transformed concentrations (ln $\mu \mathrm{M}$ ) at mid-month intervals during an example year (1995). Colour scale and contours intervals as in Fig. 3, but contours only present at log-nitrate values of 0, 1 and 2. (b) Line plots show, upper: spatially and temporally averaged (1960-2003) seasonal pattern of monthly concentrations; lower: spatially and temporally averaged long-term trend (1960-2003) in concentrations 


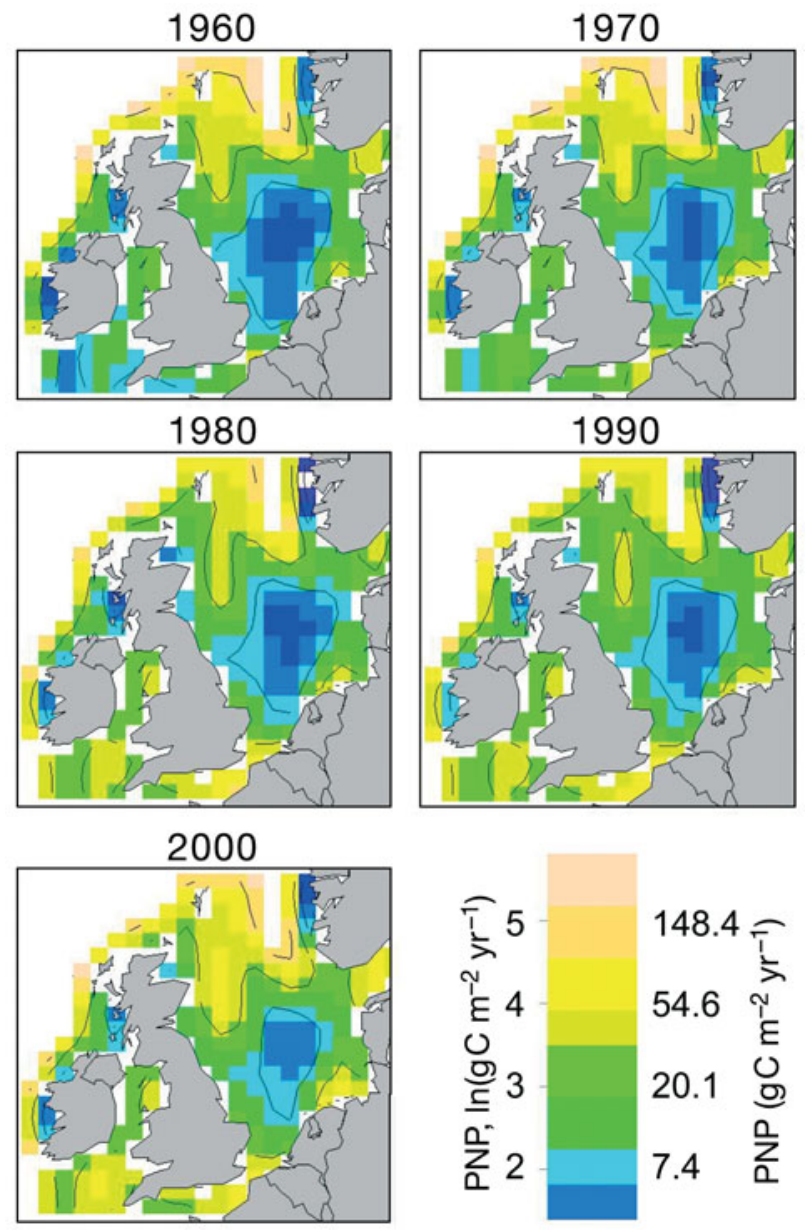

Fig. 5. Spatial distributions of $\log _{\mathrm{e}}$-transformed annual potential new primary production (PNP, $\ln \mathrm{gC} \mathrm{m}^{-2} \mathrm{yr}^{-1}$ ) at $10 \mathrm{yr}$ intervals from 1960, estimated from the draw-down of nitrate in the water column. Contours shown at log-PNP values of 3,4 and 5

extracted winter salinity observations from within the strip. The time series of 1960 to 2003 winter salinity in sections of the strip falling within assessment Regions VII, VIa and IVa are shown in Fig. 8. A period of exceptionally high salinity occurred between 1988 and 1992 in Region VII, coinciding with the pulse of PNP. This peak of salinity was also apparent in Region VIa but only weakly in Region IVa.

A subset of the winter nitrate observations in the ICES database falling within the shelf edge strip (494 observations) also had corresponding salinity measurements. Combining all years, a scatter-plot of these data (Fig. 9) indicates conservative mixing relationships between various mid-shelf and off-shelf water masses (defined by intervals of salinity and nitrate). Mid-shelf water throughout the latitude range (salinity 34.4 to 35.1 ) was characterized by nitrate concentrations between 4 and $6 \mu \mathrm{M}$. Note that the spatial selection of samples excluded inshore waters where higher nitrate concentrations were present at the lower end of this salinity range. However, 2 distinctly different high-salinity water masses were present in the outermost regions of the shelf and the adjacent off-shelf regions (upper $200 \mathrm{~m}$ of the water column above seabed depths of 400 to $2000 \mathrm{~m}$ to a maximum of $12^{\circ} \mathrm{W}$ ). North of $54^{\circ} \mathrm{N}$ (ICES Regions VIa and IVa), extremes of salinity (35.3 to 35.4) were characterized by nitrate concentrations greater than $10 \mu \mathrm{M}$, typical of the off-shelf waters in the Rockall Trough (Hydes et al. 2004). South of this latitude (ICES Region VII), a different water mass was present on the outer shelf (salinity greater than 35.5, nitrate $\sim 9 \mathrm{M}$ ), which was typical of the Celtic Sea slope waters (Hydes et al. 2004). Mixtures of inner-, midand off-shelf waters were found at various locations, particularly in the Fair Isle Current off the north of Scotland $\left(59^{\circ}\right.$ to $60^{\circ} \mathrm{N}, 2^{\circ} \mathrm{W}$ to $\left.0^{\circ}\right)$. Assuming that the winter relationship between nitrate and salinity in the main water masses remain reasonably constant over time, it is clear from these data that enhanced mixing of off-shelf water across the shelf edge will result in increased winter nitrate in the shelf waters. However, the relationship between nitrate enhancement and salinity enhancement will be distinctly different in Region VII compared to Regions VIa and IVa. We conclude that there is circumstantial evidence to support a hypothesis that the pulse of PNP in Regions VII and VIa during the early 1990s was primarily caused by unusually strong mixing of ocean water onto the continental shelf.

Monthly river nitrate fluxes through the 87 coastline segments in the hydrology data set were integrated over each of the ICES assessment regions. Changes in annual nitrate-nitrogen inputs to each region, and the mean seasonality of inputs, are shown in Fig. 10. Input to the northern North Sea and west of Scotland Regions (IVa and VI) were approximately 1 order of magnitude smaller than those to the central and southern North Sea, and the English Channel/southwest UK (IVb, IVC and VII). Peak inputs of river nutrient were during the 1980s into the southern North Sea, but inputs to this Region subsequently declined to approximately twothirds of peak values, whilst inputs to Region VII have apparently continued to increase. The seasonality of nitrate-nitrogen inputs varied from region to Region, with the greatest variation between winter and summer occurring in Region VII and the least in Region IVa.

Annual atmospheric fluxes of oxidized nitrogen to each of the ICES assessment regions were derived by averaging values for the relevant grid cells of the EMEP data set $\left(\mathrm{mg} \mathrm{N} \mathrm{m}^{-2} \mathrm{yr}^{-1}\right)$, and applying the sea surface area $\left(\mathrm{m}^{2}\right)$ of each ICES region. The results were then directly comparable with the riverine inputs to each region (Fig. 10) and showed that, at 

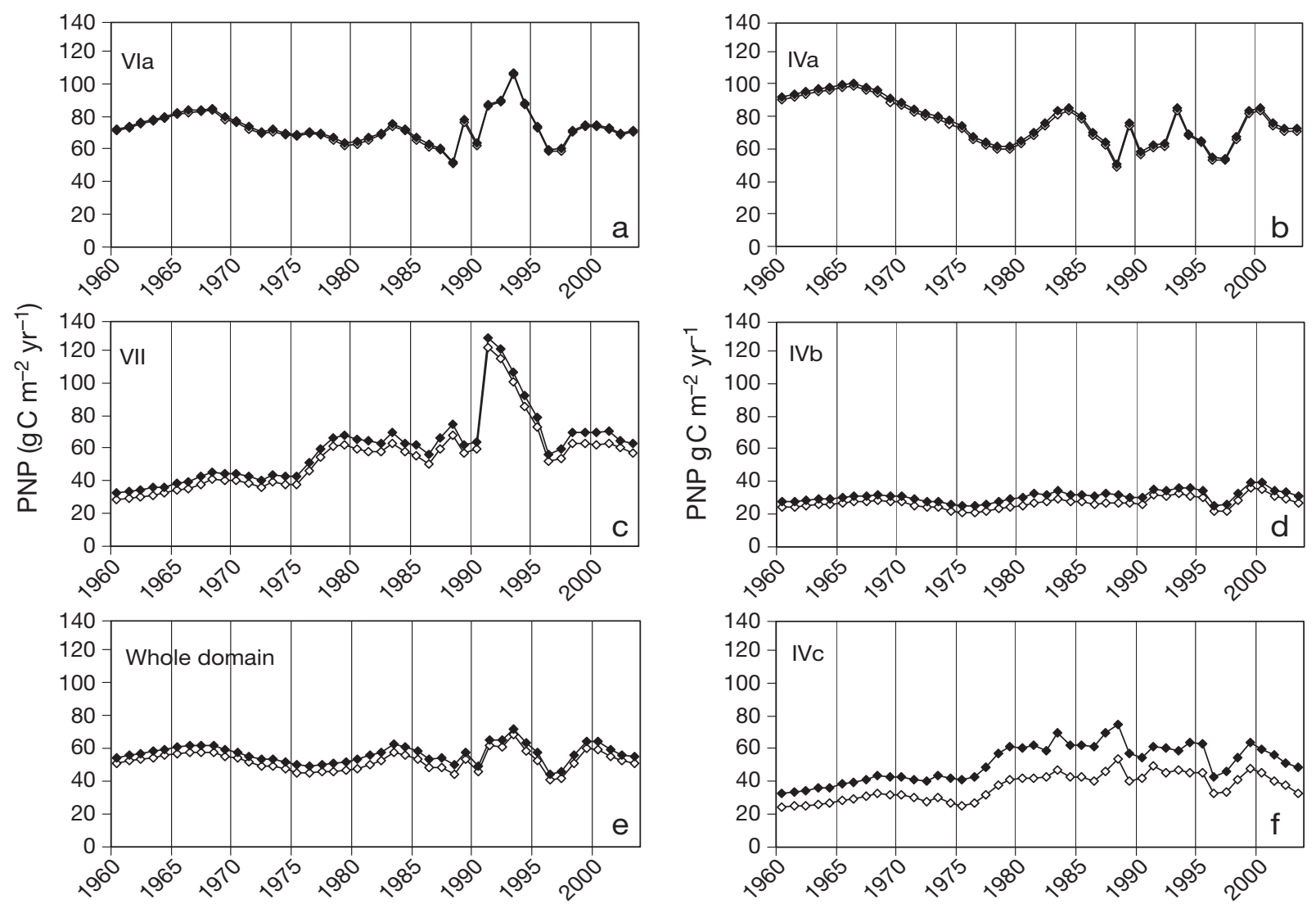

Fig. 6. Time series of annual potential new primary production (PNP) in $(a-d, f)$ each of the ICES fisheries assessment regions, $(b, d, f)$ the North Sea (Regions IVa, IVb and IVc) and (e) in the study domain as a whole. Open symbols: estimates based on water column nitrate draw-down; filled symbols: estimates including the additional contribution of river and atmospheric inputs of nitrate
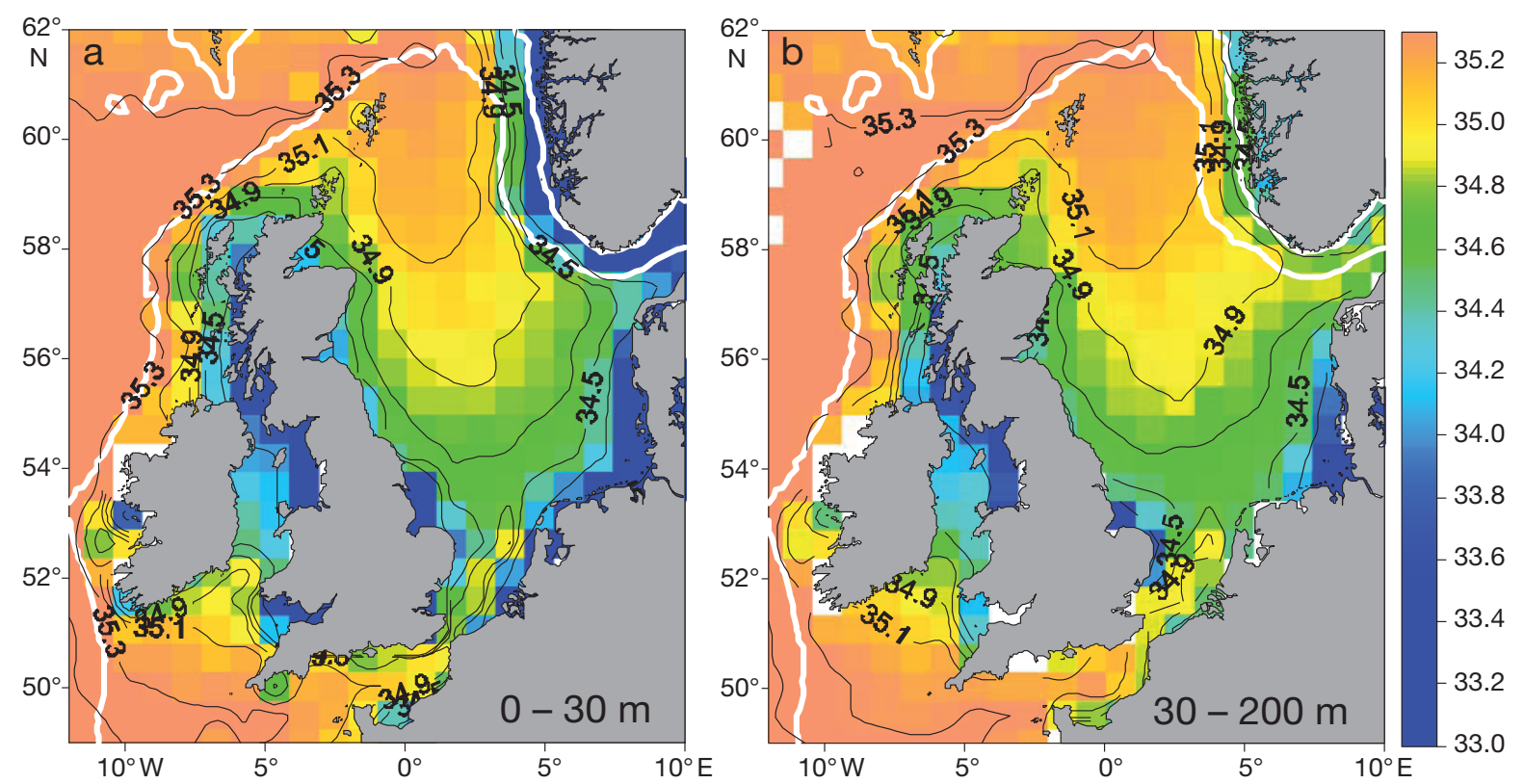

Fig. 7. Climatological (1960-1999) spatial distributions of (a) 0-30 and (b) 30-200 m salinity during November-March. Distributions derived by bin-averaging salinity observations according to $1^{\circ}$ longitude $\times 0.5^{\circ}$ latitude intervals. White contour lines indicate the $200 \mathrm{~m}$ isobath 
Table 2. Decadal means and standard deviations of potential new primary production (PNP) for various subdivisions of the study domain, with and without incorporating the effects of river and atmospheric inputs of nitrate during the spring/summer productive period (March-September)

\begin{tabular}{|c|c|c|c|c|c|c|c|c|c|c|}
\hline \multirow[t]{2}{*}{ Region } & \multicolumn{5}{|c|}{ Mean PNP $\left(\mathrm{g} \mathrm{C} \mathrm{m}^{-2} \mathrm{yr}^{-1}\right)$} & \multicolumn{5}{|c|}{ Standard deviation of PNP $\left(\mathrm{g} \mathrm{C} \mathrm{m}^{-2} \mathrm{yr}^{-1}\right)$} \\
\hline & $\begin{array}{c}1960- \\
1969\end{array}$ & $\begin{array}{c}1970- \\
1979\end{array}$ & $\begin{array}{c}1980- \\
1989\end{array}$ & $\begin{array}{c}1990- \\
1999\end{array}$ & $\begin{array}{c}2000- \\
2003\end{array}$ & $\begin{array}{c}1960- \\
1969\end{array}$ & $\begin{array}{c}1970- \\
1979\end{array}$ & $\begin{array}{c}1980- \\
1989\end{array}$ & $\begin{array}{c}1990- \\
1999\end{array}$ & $2000-$ \\
\hline \multicolumn{11}{|c|}{ Based on water column draw-down of nitrate } \\
\hline IVa & 94.1 & 72.2 & 70.2 & 64.7 & 75.0 & 3.2 & 9.8 & 10.4 & 10.7 & 5.8 \\
\hline $\mathrm{IVb}$ & 26.4 & 23.4 & 27.1 & 29.1 & 30.5 & 1.5 & 2.1 & 1.1 & 4.5 & 3.4 \\
\hline IVC & 28.0 & 30.9 & 43.9 & 43.1 & 39.0 & 3.0 & 4.9 & 4.1 & 5.8 & 5.1 \\
\hline VIa & 78.3 & 69.3 & 65.6 & 76.4 & 71.2 & 4.3 & 3.7 & 7.5 & 15.3 & 2.2 \\
\hline VII & 34.0 & 45.4 & 58.7 & 78.6 & 60.7 & 4.6 & 10.1 & 4.8 & 25.8 & 2.8 \\
\hline North Sea & 55.7 & 45.0 & 47.1 & 45.6 & 50.4 & 1.9 & 4.7 & 4.7 & 6.9 & 4.5 \\
\hline Mixed & 32.7 & 38.1 & 52.3 & 55.7 & 46.9 & 3.6 & 6.6 & 4.8 & 11.6 & 4.5 \\
\hline Frontal & 27.0 & 25.8 & 30.4 & 37.5 & 34.3 & 2.0 & 2.5 & 1.4 & 8.0 & 3.2 \\
\hline Stratified & 62.9 & 51.6 & 51.7 & 53.1 & 56.9 & 2.2 & 4.9 & 6.0 & 8.4 & 4.0 \\
\hline Whole domain & 55.2 & 48.0 & 51.0 & 54.0 & 54.3 & 2.4 & 3.0 & 4.0 & 9.1 & 3.9 \\
\hline \multicolumn{11}{|c|}{ Based on water column draw-down of nitrate plus river and atmospheric inputs } \\
\hline IVa & 96.1 & 74.2 & 72.0 & 66.2 & 76.5 & 3.2 & 9.8 & 10.4 & 10.7 & 5.9 \\
\hline $\mathrm{IVb}$ & 29.9 & 27.4 & 31.9 & 32.9 & 34.3 & 1.6 & 2.0 & 1.1 & 4.6 & 3.5 \\
\hline IVc & 37.8 & 46.0 & 63.6 & 56.7 & 53.7 & 3.8 & 7.3 & 5.7 & 7.4 & 5.0 \\
\hline VIa & 79.4 & 70.3 & 66.7 & 77.4 & 72.0 & 4.3 & 3.7 & 7.5 & 15.3 & 2.2 \\
\hline VII & 38.5 & 50.2 & 64.5 & 84.4 & 67.1 & 4.8 & 10.5 & 4.9 & 25.7 & 3.8 \\
\hline North Sea & 59.5 & 49.9 & 52.9 & 50.0 & 54.9 & 2.0 & 4.2 & 4.4 & 7.1 & 4.5 \\
\hline Mixed & 41.2 & 49.1 & 66.2 & 67.2 & 59.3 & 4.2 & 8.1 & 5.6 & 11.9 & 5.5 \\
\hline Frontal & 32.8 & 34.3 & 42.7 & 46.5 & 43.4 & 2.3 & 3.5 & 3.2 & 8.2 & 3.1 \\
\hline Stratified & 65.1 & 53.8 & 53.8 & 54.9 & 58.6 & 2.2 & 4.9 & 6.0 & 8.5 & 4.1 \\
\hline Whole domain & 58.8 & 52.3 & 56.1 & 58.2 & 58.6 & 2.5 & 2.6 & 3.8 & 9.2 & 4.0 \\
\hline
\end{tabular}
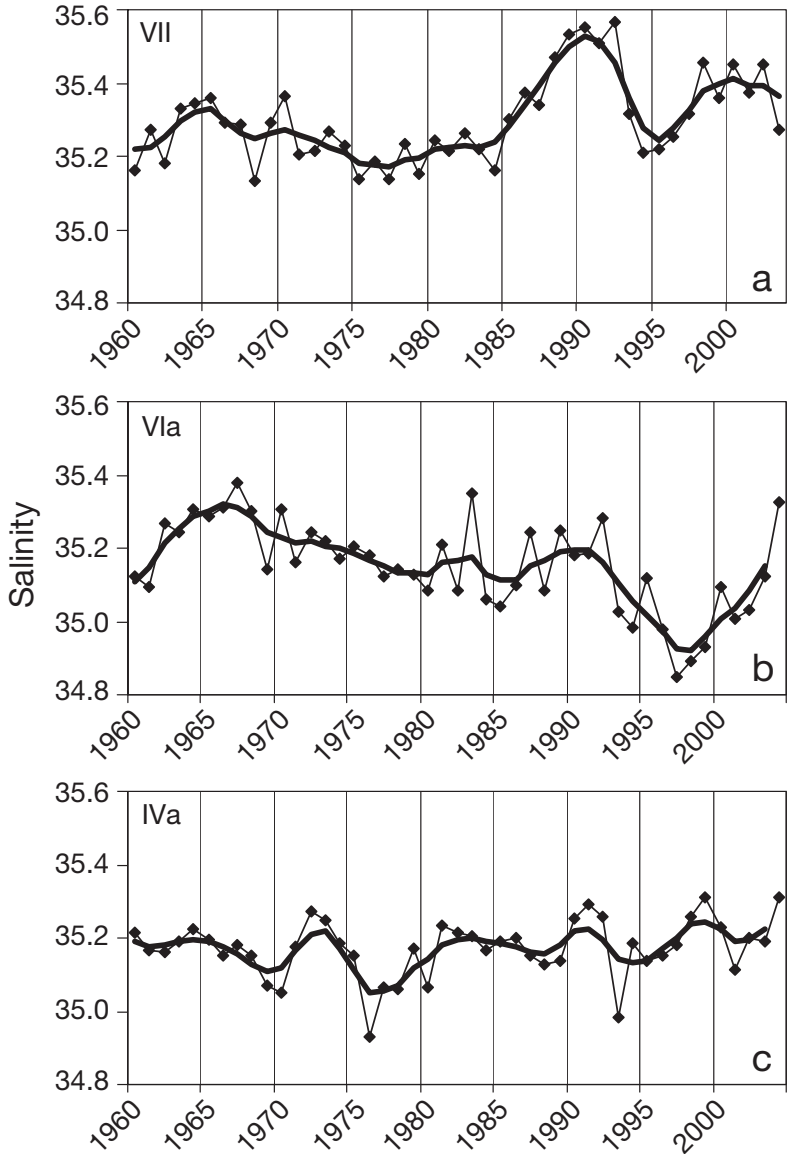

the scale of the ICES regions, annual atmospheric inputs to the northern part of the study region (Via, $\mathrm{IVa}$ and $\mathrm{IVb}$ ) were equivalent to, or greater than, river inputs. However, in the southern regions (VIC and VII) the river inputs exceeded atmospheric deposition by approximately an order of magnitude. EMEP data were available only in 5 yr intervals from 1980 to 2000 , but showed a declining trend of deposition in all regions.

The time series of annual PNP in the southern North Sea (Region IVc) was significantly cross-correlated with annual river nitrate flux $\left(\mathrm{r}=0.77, \mathrm{r}_{\text {critical }}=\right.$ 0.71 at $\mathrm{p}<0.05, \mathrm{r}_{\text {critical }}=0.83$ at $\mathrm{p}<0.01$, modified degrees of freedom $=7.0$ according to the modified Chelton method, MCM; to account for serial autocorrelation, Pyper \& Peterman 1998). Time series of PNP were not significantly correlated with river fluxes in any of the other regions, according to the MCM. We conclude that river inputs since 1960 have significantly affected winter nitrate concentrations in the southern North Sea, leading to changes in the seasonal draw-down of nitrate in the water column and hence our estimates of PNP. There were too few esti-

Fig. 8. Time series of spatially averaged winter (NovemberMarch) salinity for outer shelf regions (within $200 \mathrm{~km}$ of the $200 \mathrm{~m}$ isobath) in ICES Regions (a) VII, (b) VIa and (c) IVa. Heavy lines represent moving averages of the data values 


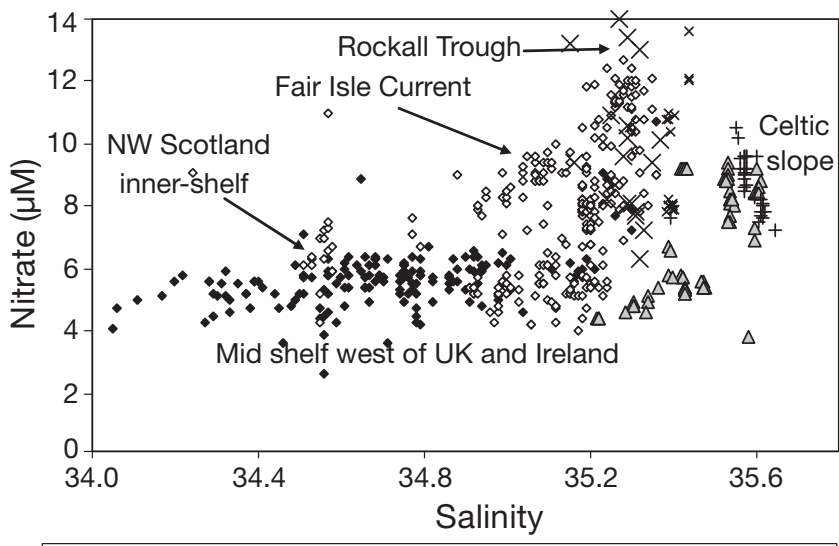

$\triangle 48^{\circ}-54^{\circ} \mathrm{N}<200 \mathrm{~m} \cdot 54^{\circ}-58^{\circ} \mathrm{N}<200 \mathrm{~m} \quad \circ 58^{\circ}-62^{\circ} \mathrm{N}<200 \mathrm{~m}$ $+48^{\circ}-54^{\circ} \mathrm{N}>400 \mathrm{~m} \times 54^{\circ}-58^{\circ} \mathrm{N}>400 \mathrm{~m} \times 58^{\circ}-62^{\circ} \mathrm{N}>400 \mathrm{~m}$

Fig. 9. Salinity and nitrate measurements on water samples collected between the sea surface and $200 \mathrm{~m}$ depth from different latitude intervals on the outer shelf (within $200 \mathrm{~km}$ on the landward side of the $200 \mathrm{~m}$ isobath: closed symbols) and over the continental slope (above seabed depths of $400-2000 \mathrm{~m}$ to a maximum of $12^{\circ} \mathrm{W}$ : cross-symbols), during November-March, 1960-1999. Geographical locations of samples characteristic of different water types indicated by the text labels mates of atmospheric deposition to determine meaningful correlations with PNP.

The additional contributions of river and atmospheric inputs to our draw-down estimates of ICES regional PNP were determined by assuming that all inputs of nitrate (oxidized nitrogen) during the springsummer productive period (March through September) contributed directly to PNP and Redfield correspondence between nitrate uptake and carbon fixation (Eq. 4). In the case of atmospheric inputs, we had no information on the seasonal distribution of regional averaged deposition rates (mmol $\mathrm{N} \mathrm{m}^{-2} \mathrm{yr}^{-1}$ ), so we assumed that the annual deposition was distributed uniformly over the year. In addition, we lineally interpolated the values in the intervening years between the 5 yr estimates from EMEP and assumed a constant rate of deposition over all years between 1960 and 1980, and between 2000 and 2003. In the case of rivers, we estimated the area flux density of nitrate input to each region ( $\mathrm{mmol} \mathrm{N} \mathrm{m}^{-2} \mathrm{yr}^{-1}$ ) by assuming that the March through September input was distributed over the sea surface areas with seabed depth <200 m (IVa: $201547 \mathrm{~km}^{2}$, IVb: 287965 km², IVc:
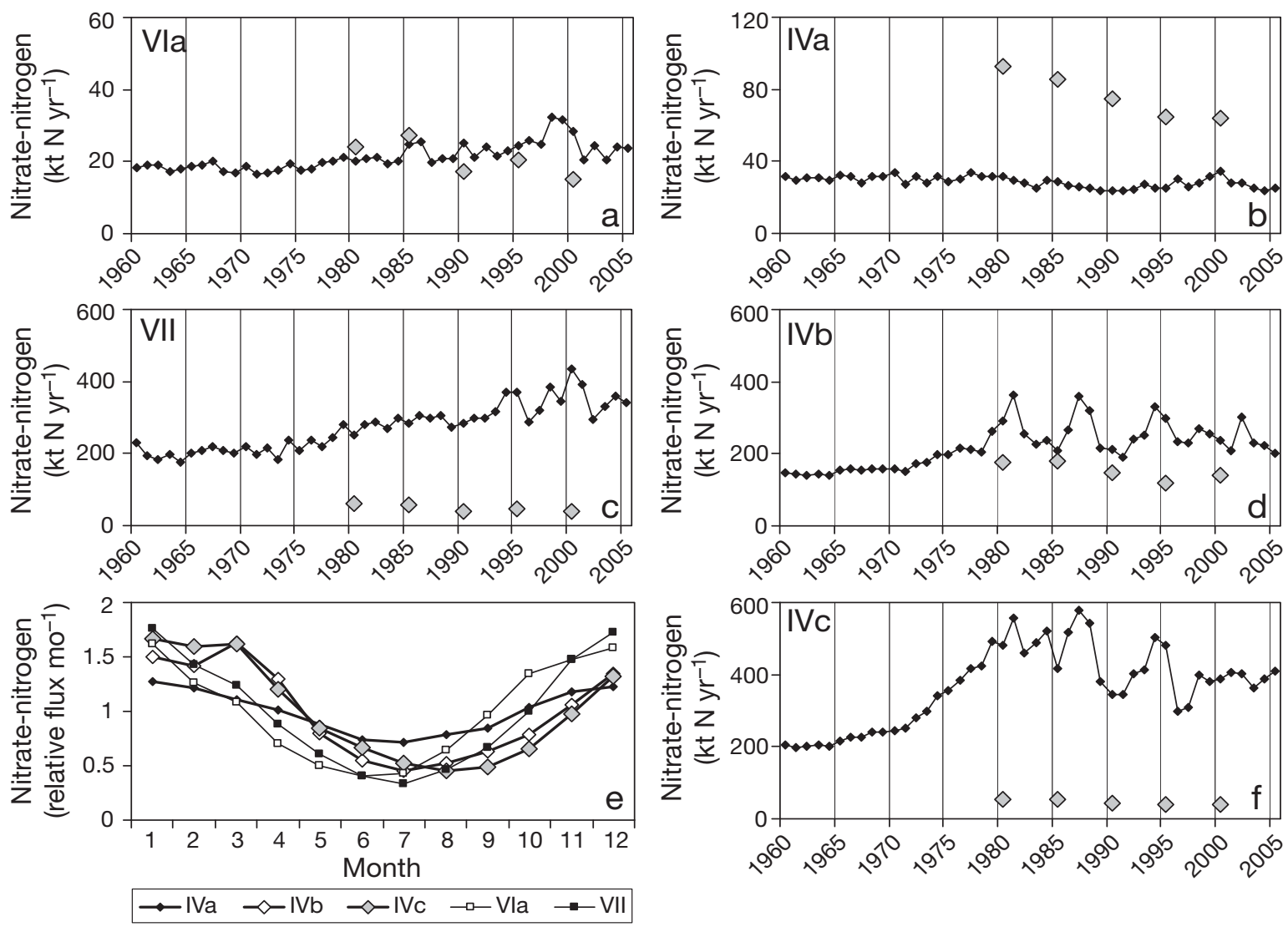

Fig. 10. (a-d,f) Annual inputs of nitrate-nitrogen ( $\mathrm{kt} \mathrm{yr}^{-1}$ ) from rivers (black filled symbols) and atmospheric deposition (grey filled symbols; data available only for 1980, 1985, 1990, 1995 and 2000) to each of the ICES fisheries assessment regions. (e) Mean seasonality of river nutrient inputs to each of the assessment regions, expressed as the relative monthly input (average monthly input/annual average monthly input) 
$79791 \mathrm{~km}^{2}$, VI: $117272 \mathrm{~km}^{2}$, VII: $142517 \mathrm{~km}^{2}$ ). Inputs of nitrate from rivers during March-September outweighed those from the atmosphere in the southern regions (IVC 6.7:1 and VII 3.3:1, averaged over 1960 to 2003), whilst the reverse was the case in the northern regions (VIa 0.6:1 and IVa 0.3:1). Inputs to the central North Sea (Region IVb) from rivers and the atmosphere were approximately equal in magnitude. The enhancements of PNP $\left(\mathrm{g} \mathrm{C} \mathrm{m}^{-2} \mathrm{yr}^{-1}\right)$ due to river inputs and atmospheric deposition were greatest in the southern North Sea (Region IVc, 1960 to 2003 average due to rivers $12.6 \mathrm{~g} \mathrm{C} \mathrm{m}^{-2} \mathrm{yr}^{-1}$, average due to atmospheric deposition $2.0 \mathrm{gC} \mathrm{m}^{-2} \mathrm{yr}^{-1}$ ), and least off the west of Scotland (Region VIa, 1960 to 2003 average due to rivers $0.4 \mathrm{gC} \mathrm{m}^{-2} \mathrm{yr}^{-1}$, average due to atmospheric deposition $0.6 \mathrm{~g} \mathrm{C} \mathrm{m}^{-2} \mathrm{yr}^{-1}$ ). Combining the PNP estimates based on water column draw-down with the additional contributions from river and atmospheric inputs (Table 2), resulted in 1960 to 2003 averages of total PNP ranging from $31 \mathrm{~g} \mathrm{C} \mathrm{m}^{-2} \mathrm{yr}^{-1}$ in the central North Sea (Region IVb) to $77 \mathrm{~g} \mathrm{C} \mathrm{m}^{-2} \mathrm{yr}^{-1}$ in the northern North Sea (Region IVa) (Fig. 6). The proportion of total annual PNP accounted for by March through September river inputs varied between $<1 \%$ in the northern North Sea and west of Scotland (Regions IVa and VIa), and $>20 \%$ in the southern North Sea (Region IVc) (Table 3). Corresponding atmospheric inputs accounted for $<1 \%$ of annual PNP off the west of Scotland and $6 \%$ in the central North Sea (Region $\mathrm{IVb})$.

In each region, a proportion of the total annual PNP was due to vertical fluxes of nitrate from below the $30 \mathrm{~m}$ depth horizon into the surface layer, where it was assimilated by phytoplankton. We estimated the vertical flux (mmol N m${ }^{-2} \mathrm{yr}^{-1}$ ) from Eq. (2), the contribution to PNP $\left(\mathrm{gC} \mathrm{m}^{-2} \mathrm{yr}^{-1}\right)$ by assuming Redfield proportionality between nitrate flux and carbon uptake (as in Eq. 4), and expressed the results as a proportion of the total annual PNP including river and atmospheric inputs. The proportion (Table 4) ranged from $71 \%$ (1960 to 2003 average) in the northern North Sea (Region IVa), to $2 \%$ in the southern North Sea (Region IVc). In the deeper, northern regions (IVa and VIa), the average proportion approached the fraction of regional volume which was deeper than $30 \mathrm{~m}$, whilst in the shallower southern regions the proportion of PNP accounted for by vertical flux was disproportionately small compared to the distribution of depths (Fig. 11).
The spatial distributions of mixed, frontal and stratified zones based on the Simpson-Hunter stratification index are shown in Fig. 12. Averaged over each of these zones, the water column draw-down results suggested that frontal zones had the lowest 1960 to 2003

Table 3. Decadal means of the proportions of total annual potential new primary production (PNP) contributed by spring/summer (March-September) fluxes of oxidized nitrogen from rivers and atmospheric deposition to the various subdivisions of the study domain

\begin{tabular}{|lccccc|}
\hline \multirow{2}{*}{ Region } & \multicolumn{5}{c|}{ Proportion of annual PNP } \\
\multicolumn{1}{c}{$1960-$} & $1970-$ & $1980-$ & $1990-$ & $2000-$ \\
& 1969 & 1979 & 1989 & 1999 & 2003 \\
\hline Riverine fluxes & & & & & \\
IVa & 0.005 & 0.006 & 0.006 & 0.006 & 0.005 \\
IVb & 0.048 & 0.071 & 0.088 & 0.069 & 0.065 \\
IVc & 0.200 & 0.280 & 0.276 & 0.211 & 0.242 \\
VIa & 0.005 & 0.005 & 0.006 & 0.006 & 0.006 \\
VII & 0.081 & 0.068 & 0.071 & 0.057 & 0.081 \\
North Sea & 0.033 & 0.059 & 0.076 & 0.059 & 0.056 \\
Mixed & 0.164 & 0.188 & 0.186 & 0.152 & 0.188 \\
Frontal & 0.130 & 0.204 & 0.253 & 0.168 & 0.184 \\
Stratified & 0.008 & 0.010 & 0.010 & 0.010 & 0.009 \\
Whole domain & 0.033 & 0.051 & 0.064 & 0.050 & 0.053 \\
Atmospheric fluxes & & & & \\
IVa & 0.016 & 0.021 & 0.020 & 0.017 & 0.014 \\
IVb & 0.067 & 0.074 & 0.062 & 0.046 & 0.047 \\
IVc & 0.058 & 0.048 & 0.034 & 0.030 & 0.032 \\
VIa & 0.009 & 0.010 & 0.010 & 0.007 & 0.006 \\
VII & 0.036 & 0.027 & 0.019 & 0.012 & 0.014 \\
North Sea & 0.031 & 0.038 & 0.034 & 0.028 & 0.026 \\
Mixed & 0.043 & 0.036 & 0.025 & 0.019 & 0.021 \\
Frontal & 0.046 & 0.044 & 0.034 & 0.024 & 0.025 \\
Stratified & 0.026 & 0.031 & 0.030 & 0.023 & 0.021 \\
Whole domain & 0.028 & 0.031 & 0.028 & 0.021 & 0.020 \\
\hline & & & & & \\
\hline
\end{tabular}

Table 4. Decadal means of the proportions of total annual potential new primary production (PNP) due to vertical fluxes of oxidized nitrogen from below the $30 \mathrm{~m}$ depth horizon in the various subdivisions of the study domain, together with bathymetric and volumetric parameters. Volumetric proportion was derived by averaging the thickness of the surface and deep layers at each node of the PNP data set, taking account of seabed depth.

\begin{tabular}{|c|c|c|c|c|c|c|c|}
\hline Region & $\begin{array}{r}\text { Prc } \\
\\
1960- \\
1969\end{array}$ & $\begin{array}{c}\text { oportio } \\
\text { due to } \\
1970- \\
1979\end{array}$ & $\begin{array}{c}n \text { of anr } \\
\text { vertica } \\
1980- \\
1989\end{array}$ & $\begin{array}{l}\text { nual PN } \\
1 \text { flux } \\
1990- \\
1999\end{array}$ & $\begin{array}{l}\text { ND } \\
2000- \\
2003\end{array}$ & $\begin{array}{c}\text { Bathyn } \\
\text { volumetric } \\
\text { Mean } \\
\text { depth }(\mathrm{m})\end{array}$ & $\begin{array}{l}\text { metric and } \\
\text { characteristics } \\
\text { Proportion of } \\
\text { volume deeper } \\
\text { than } 30 \mathrm{~m}\end{array}$ \\
\hline IVa & 0.63 & 0.72 & 0.75 & 0.71 & 0.67 & 98 & 0.71 \\
\hline $\mathrm{IVb}$ & 0.27 & 0.31 & 0.30 & 0.32 & 0.31 & 52 & 0.46 \\
\hline IVC & 0.02 & 0.02 & 0.02 & 0.03 & 0.03 & 24 & 0.07 \\
\hline VIa & 0.54 & 0.59 & 0.58 & 0.59 & 0.61 & 78 & 0.65 \\
\hline VII & 0.30 & 0.34 & 0.28 & 0.44 & 0.45 & 67 & 0.55 \\
\hline North Sea & 0.51 & 0.54 & 0.53 & 0.51 & 0.50 & 69 & 0.60 \\
\hline Mixed & 0.10 & 0.11 & 0.09 & 0.15 & 0.15 & 37 & 0.29 \\
\hline Frontal & 0.16 & 0.20 & 0.17 & 0.27 & 0.25 & 39 & 0.41 \\
\hline Stratified & 0.57 & 0.65 & 0.66 & 0.72 & 0.67 & 80 & 0.65 \\
\hline Whole domain & 0.49 & 0.52 & 0.49 & 0.51 & 0.51 & 70 & 0.60 \\
\hline
\end{tabular}




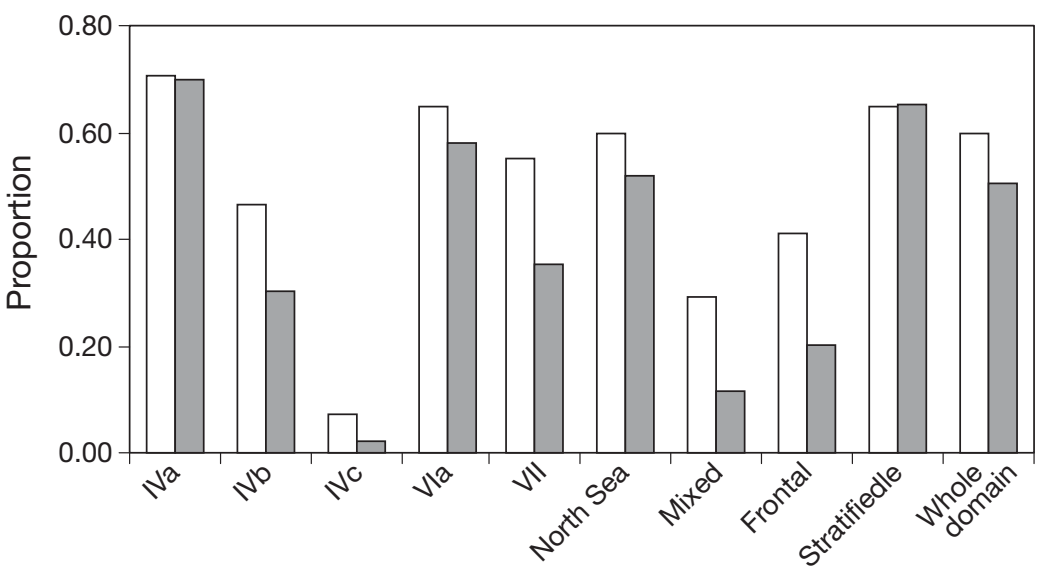

Proportion of volume deeper than $30 \mathrm{~m}$

Mean proportion of PNP due to vertical flux from below $30 \mathrm{~m}$

Fig. 11. Proportion of volume in each region deeper than $30 \mathrm{~m}$ (open bars) compared to proportion of annual potential new primary production (PNP) accounted for by vertical fluxes of nitrate from below the $30 \mathrm{~m}$ depth horizon (filled bars). Volumetric ratio derived by averaging the thickness of the surface and deep layers at each node of the PNP data set, taking account of seabed depth at each node average PNP $\left(31 \mathrm{~g} \mathrm{C} \mathrm{m}^{-2} \mathrm{yr}^{-1}\right)$, and stratified zones the highest $\left(55 \mathrm{gC} \mathrm{m}^{-2} \mathrm{yr}^{-1}\right)$, with mixed waters in between $(45 \mathrm{gC}$ $\left.\mathrm{m}^{-2} \mathrm{yr}^{-1}\right)$. Inclusion of March through September river and atmospheric inputs raising the 1960 to 2003 average PNP in mixed waters to $56 \mathrm{gC} \mathrm{m}^{-2} \mathrm{yr}^{-1}$, whilst frontal and stratified waters were increased to $39 \mathrm{gC} \mathrm{m}^{-2} \mathrm{yr}^{-1}$ and $57 \mathrm{gC}$ $\mathrm{m}^{-2} \mathrm{yr}^{-1}$, respectively. However, between the mid 1970s and mid 1990s, river inputs raised the PNP of mixed waters to higher than that for stratified waters, having been substantially lower in the 1960s (Fig. 12). The contribution of river inputs to total annual PNP exceeded that from atmospheric deposition in the mixed and frontal zones (6.1:1 and 5.7:1, respectively), but was less than due to atmospheric deposition for the stratified zone (0.3:1). Decadal average values of total PNP (including river and atmospheric inputs) in each of the stratification zones are shown in Table 4. Vertical fluxes accounted for an
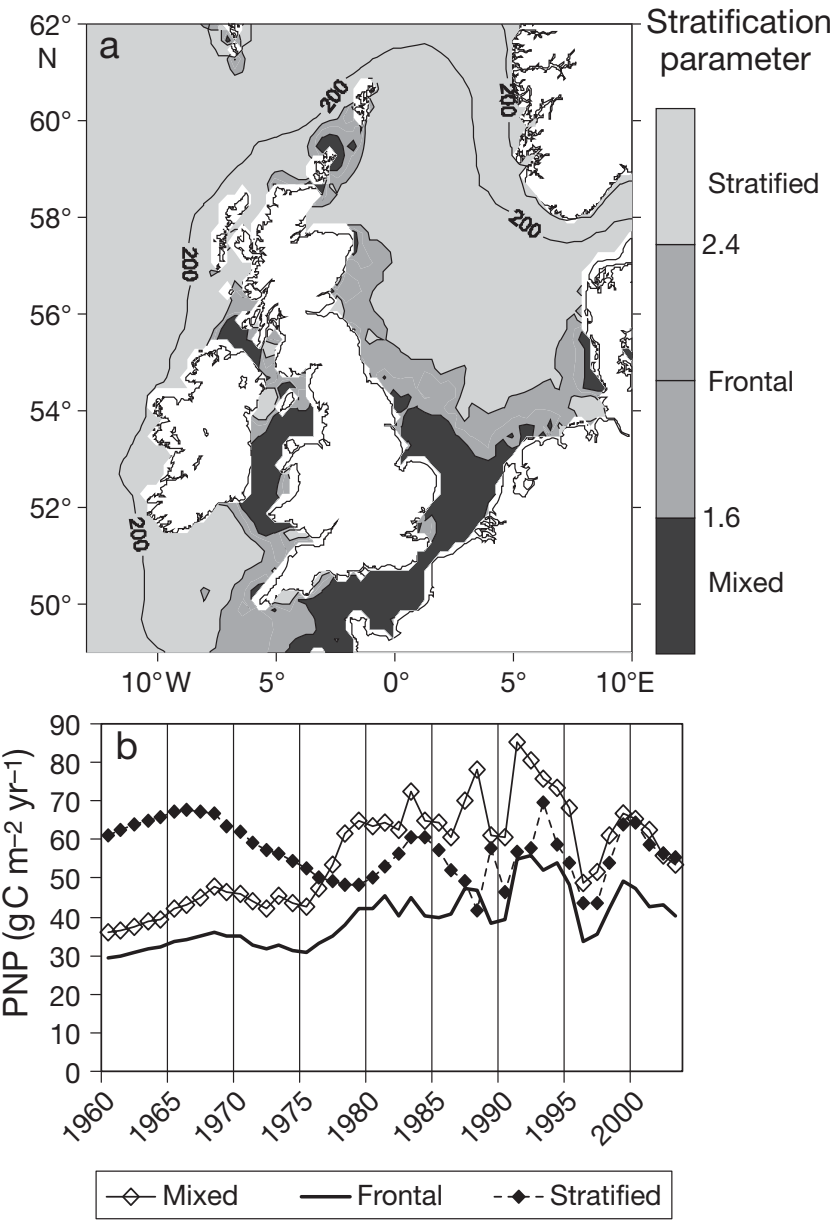
average of $65 \%$ of total PNP in the stratified zone, which was in accordance with the distribution of regional volume above and below the $30 \mathrm{~m}$ depth horizon (Table 4). In the frontal zones, vertical fluxes accounted for $20 \%$ of annual PNP, and $11 \%$ in mixed waters, and were disproportionately small compared to the distributions of volume between depth layers. Time series of the proportion of annual PNP accounted for by vertical flux (Fig. 13) showed an increasing longterm trend in mixed, frontal and stratified zones. In the mixed and frontal zones, changes in the contribution of river and atmospheric inputs to the surface layer formed a component of the trend in the proportional contribution of vertical flux. However, in the stratified zone, where river and atmospheric inputs were of lesser significance, the trend presumably reflected changes in oceanographic processes affecting the intensity of stratification and vertical mixing. Many of these processes are encapsulated by the winter North Atlantic Oscillation (NAO) index (Hurrell et al. 2003), and a 3 yr running mean of the winter NAO (December to March station-based index; www.cgd.ucar.edu/ cas/jhurrell/indices.data. html\#nam, last accessed 1 February 2008) was significantly correlated $(0.01<\mathrm{p}<$

Fig. 12. (a) Spatial distributions of regions denoted mixed, frontal and stratified according to the Simpson-Hunter tidal stratification index. (b) Potential new primary production (PNP) in each region including the estimated contribution of river and atmospheric inputs 

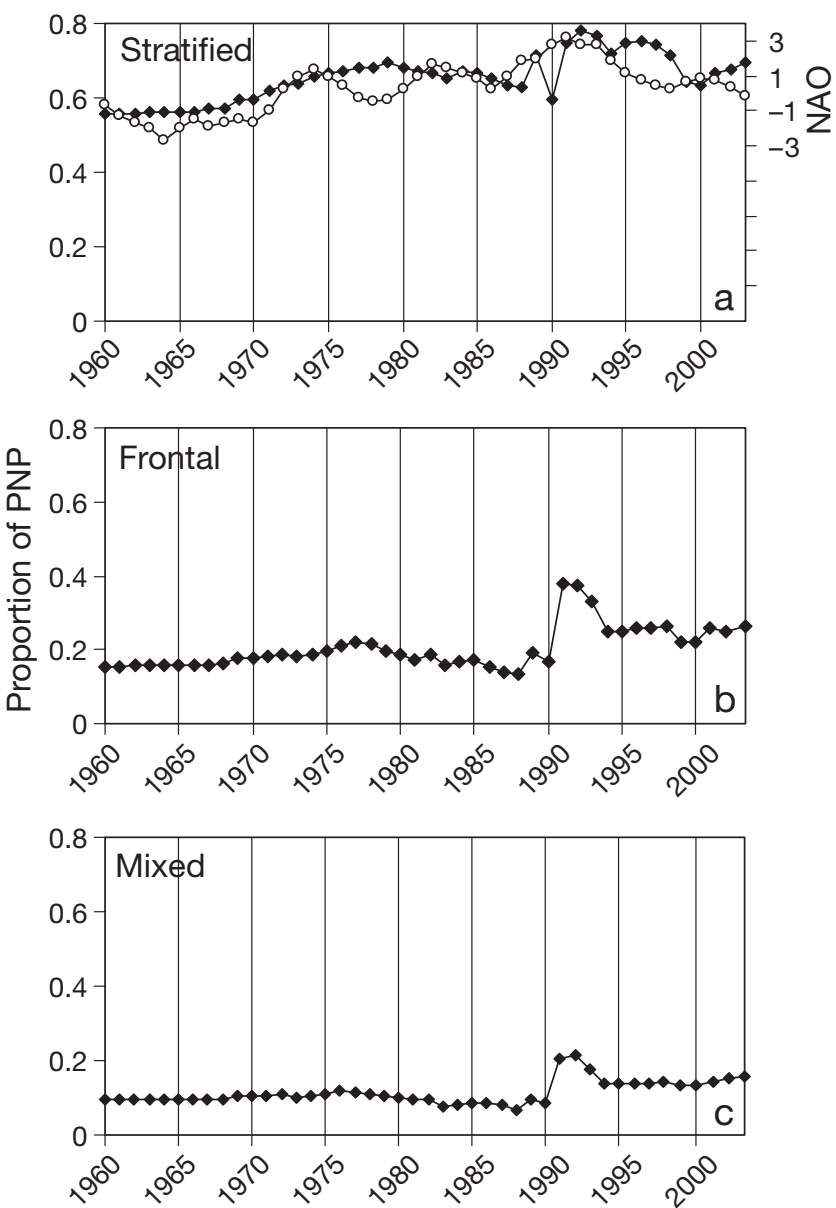

Fig. 13. Time series of the annual proportion of potential new primary production (PNP) accounted for by vertical fluxes of nitrate from below the $30 \mathrm{~m}$ depth horizon in (a) stratified, (b) frontal and (c) mixed zones (filled symbols). In (a) open symbols represent the $3 \mathrm{yr}$ moving average time series of the North Atlantic Oscillation (NAO) index

0.05) with the proportion of PNP accounted for by vertical flux in the stratified zone (Table 5). The additional variability in the unsmoothed NAO time series resulted in weaker correlation $(0.05<\mathrm{p}<0.10)$.

\section{DISCUSSION}

\section{Overall levels of new production}

Previous studies have estimated new primary production to be around $40 \mathrm{~g} \mathrm{C} \mathrm{m}^{-2} \mathrm{yr}^{-1}$ (503 mmol N m${ }^{-2}$ $\mathrm{yr}^{-1}$ ) in the Dogger Bank area by direct measurements (Richardson et al. 2000) and between 30 and $100 \mathrm{gC}$ $\mathrm{m}^{-2} \mathrm{yr}^{-1}$ (378 to $1258 \mathrm{mmol} \mathrm{N} \mathrm{m}^{-2} \mathrm{yr}^{-1}$ ) in the North Sea as a whole from nutrient budgets (Steele 1974, Richardson \& Pedersen 1998). There have been no previous estimates of annual new production for shelf regions to the west of the UK and no spatially resolved estimates on the scale presented here. Radach \& Gekeler (1996) derived a climatological annual cycle of spatially interpolated nutrient distributions for the same study area which was consistent with our GAM results for the same period, but did not attempt to estimate the implied new production. Spatial distributions of total annual primary production (e.g. Behrenfeld \& Falkowski $1997)$ and the ratio of new:total primary production (Laws et al. 2000) have been derived from ocean colour data, but these suffer from the uncertainties referred to earlier associated with chlorophyll calibration of reflectance data from shallow shelf waters and the role of deep chlorophyll maxima (see 'Role of stratification'), which are not detectable by remote sensing. So, whilst our regional estimates of new production seem to be within the range of those derived previously, there are few truly comparable studies.

\section{Role of stratification}

Our results show that in the seasonally stratified waters of the northern North Sea and west of Scotland, vertical fluxes of nitrate from below the thermocline make a large contribution to annual PNP. The contribution was approximately in proportion to the relative distribution of regional volume above and below the seasonal thermocline depth $(70 \%$ of volume deeper

Table 5. Time-series correlations between the proportion of annual potential new primary production (PNP, including contributions from rivers and atmosphere) accounted for by the vertical flux of nitrate from below $30 \mathrm{~m}$, and the winter North Atlantic Oscillation (NAO) index (December-March station based NAO index; www.cgd.ucar.edu/cas/jhurrell/indices.data.html\#nam, last accessed 1 February 2008). Correlation analyses according the Modified Chelton Method (MCM; Pyper \& Peterman 1998) in which $r_{\text {critical }}$ is the minimum correlation coefficient for significance given the modified degrees of freedom

\begin{tabular}{|llcccrc|}
\hline Zone & NAO series & $\begin{array}{c}\text { Correlation } \\
\text { coefficient }(\mathrm{r})\end{array}$ & $\begin{array}{c}\text { Modified degrees } \\
\text { of freedom }\end{array}$ & $\begin{array}{c}\mathrm{r}_{\text {critical }} \text { at } \\
\mathrm{p}<0.10\end{array}$ & $\begin{array}{c}\mathrm{r}_{\text {critical }} \text { at } \\
\mathrm{p}<0.05\end{array}$ & $\begin{array}{c}\mathrm{r}_{\text {critical }} \text { at } \\
\mathrm{p}<0.01\end{array}$ \\
\hline Stratified & Annual NAO & 0.419 & 16.8 & 0.400 & 0.468 \\
Stratified & 3 yr moving average of NAO & 0.723 & 7.3 & 0.582 & 0.666 \\
Frontal & 3 yr moving average of NAO & 0.525 & 9.8 & 0.521 & 0.602 \\
Mixed & 3 yr moving average of NAO & 0.404 & 10.2 & 0.497 & 0.798 \\
\end{tabular}


than $30 \mathrm{~m}$ in the northern North Sea), implying that over the annual cycle a high proportion of the nitrate in the deep layer is withdrawn by diffusion and utilized by phytoplankton in the photic zone. During summer months the majority of primary production in the stratified parts of the northern and central North Sea is confined to a deep chlorophyll maximum (DCM) within the thermocline at approximately $30 \mathrm{~m}$ depth, supported by vertical diffusion of nutrient from the deep waters (Richardson et al. 2000, Weston et al. 2005). Based on in situ measurements in the central North Sea, Weston et al. (2005) estimated that nitrate uptake in the DCM accounted for $37 \%$ of annual new production in the seasonally stratified North Sea, whilst our results indicate $65 \%$ for the annual contribution of vertical fluxes from the deep layer in stratified waters. However, a proportion of the annual vertical flux will presumably occur during the early stages of stratification, prior to development of the DCM.

The positive time series correlation between the winter NAO index and our estimates of the proportion of PNP accounted for by vertical flux of nitrate in seasonally stratified waters gives us a hint as to one of the ways in which climatic factors may affect PNP. The precise link between the winter NAO index and our estimates of vertical flux are obscure, since the barometric pressure data upon which the NAO index is based are seasonally disconnected from the timing of the vertical fluxes of nitrate. However, the evidence suggests that the winter index reflects macro-scale aspects of climate that, in the northeast Atlantic, are reflected in positive relationships with annual measures of sea surface temperature and wind stress (Hurrell et al. 2003), which in turn affect vertical diffusion and mixing. The high NAO index phase during the mid 1990s coincided with a period when our analysis shows that vertical fluxes contributed a particularly large fraction of annual PNP.

\section{Production in frontal zones}

According to our analysis, tidal frontal zones support minimum rates of new production, even after the inclusion of riverine and atmospheric inputs. This conclusion appears, at first sight, to be highly contrary to accepted wisdom regarding the high productivity of frontal regions (LeFevre 1986). However, many studies of frontal production have been based on total production (new + recycled) rather than solely new production. Richardson et al. (2000) estimated the annual new production of the Dogger Bank tidal front to be 24 to $48 \mathrm{~g} \mathrm{C} \mathrm{m}^{-2}$ $\mathrm{yr}^{-1}$, based on direct observations and estimates of the horizontal injection of nitrate into the frontal zone from below the thermocline on the stratified side of the front, whilst Richardson \& Pedersen (1998) estimated the PNP of North Sea frontal zones to be approximately $30 \mathrm{~g} \mathrm{C}$

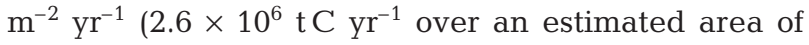
$85896 \mathrm{~km}^{2}$ ). Both of these estimates for frontal zones are close to our results based on the combination of water column draw-down, river and atmospheric inputs $\left(39 \mathrm{~g} \mathrm{C} \mathrm{m}^{-2} \mathrm{yr}^{-1}\right)$. In contrast, spatial distributions of total production based on ocean colour remote-sensing data (e.g. Behrenfeld \& Falkowski 1997) indicate rates in the southern part of the North Sea, English Channel and Irish Sea to be $>300 \mathrm{~g} \mathrm{C} \mathrm{m}^{-2} \mathrm{yr}^{-1}$, and 200 to $300 \mathrm{~g} \mathrm{C} \mathrm{m}^{-2}$ $\mathrm{yr}^{-1}$ in the northwestern North Sea. Moll (1997) and Charnock et al. (1994) reviewed model and observational data on primary production and concluded that total production is approximately $120 \mathrm{~g} \mathrm{C} \mathrm{m}^{-2} \mathrm{yr}^{-1}$ in stratified areas and $200 \mathrm{~g} \mathrm{C} \mathrm{m}^{-2} \mathrm{yr}^{-1}$ in coastal waters, with the mean production in the North Sea as a whole being $145 \mathrm{~g} \mathrm{C} \mathrm{m}^{-2} \mathrm{yr}^{-1}$. The implication is that there are strong spatial variations in the annual $f$-ratio (proportion of total production accounted for by new uptake) from 0.1 to 0.2 in the frontal and well-mixed central and southern North Sea to $\sim 0.3$ in the stratified northern North Sea. Unless horizontal fluxes of nitrate are particularly significant, tidal frontal zones would therefore appear to be the loci of exceptionally high turnover and recycled production, rather than new production. However, this conclusion contrasts with that of Horne et al. (1989) and Franks \& Chen (1996), who showed that the $f$-ratio in frontal zones around the Georges Bank (northwestern Atlantic) was as high as 0.7, supported by fluxes of nitrate into the front from beneath the thermocline on the stratified side. But the seabed depth on the stratified side of the Georges Bank fronts extends to $>200 \mathrm{~m}$, compared to $70 \mathrm{~m}$ in the North Sea, so there exists a significantly larger pool of sub-photic zone nitrate to support frontal production around Georges Bank. In addition, the North Sea frontal zones are in the interior of the shelf, remote from river inputs, and winter nitrate concentrations in the area were consistently the lowest over the study domain. The likely implication is that the ratio of denitrification to external inputs plus regeneration is higher in the central North Sea than in other regions, restricting the mass of nitrate that can accumulate in the water column before the start of the next productive season (see also Hydes et al. 1999, 2004).

\section{Role of river inputs}

Our analysis shows that at the scale of the ICES assessment regions, river inputs of nitrate during the spring and summer make the greatest contribution to PNP (24\%, equivalent to $12.5 \mathrm{~g} \mathrm{C} \mathrm{m}^{-2} \mathrm{yr}^{-1}$ averaged over 1960 to 2003) in the southern North Sea (ICES region IVc), 
which receives discharge from the major continental European rivers (Elbe, Ems, Meuse, Rhine and Weser). Spring and summer river inputs made a $5 \%$ contribution to PNP in the domain as a whole, but only $1 \%$ in the stratified zones, compared to 17 to $19 \%$ in the mixed and frontal zones. River inputs of oxidized nitrogen peaked in the 1980s and have since declined due to a variety of factors, including improved effluent treatment and changing rainfall patterns. During the 1980s, river inputs changed the balance of PNP rates between mixed and stratified zones, but since the 1990s the balance appears to have reverted as river inputs have declined (Fig. 12).

Clearly it is an exaggeration to assume that the dilution area for North Sea river inputs is as large as the ICES assessment regions. In reality, the effective dilution areas are likely to be smaller and more confined to the coastal waters so that the riverine enhancement of PNP in the continental European coastal waters is likely to be considerable. This does not invalidate our assessment of riverine contributions to PNP at the scale of ICES regions, merely indicates that the contribution is not homogeneous over each region. For example, Lenhart et al. (1997) examined the impact of river inputs on the ecosystem dynamics of the North Sea using a spatially resolved dynamic ecosystem model and concluded that the effects were minimal in the central regions, but $>30 \%$ in the coastal regions. Similarly, Radach \& Moll (2006) concluded that resolving river inputs of nutrient was essential for successful modelling of the North Sea ecosystem dynamics.

\section{Role of atmospheric inputs}

Our results indicated that, over the study area as a whole, spring and summer deposition of oxidized nitrogen from the atmosphere contributed approximately half as much annual PNP as rivers (3\% of annual PNP). Similarly, Boulart et al. (2006) estimated that wet deposition of nitrogen could account for up to $3 \%$ of new production. The contribution was least in the northern parts of the study area (IVa $2 \%$ of annual PNP, VIa $1 \%$ ), where PNP was relatively high and which were more remote from the major populated and industrial emission areas of central and southern UK, Germany and the Netherlands. In contrast, spring and summer atmospheric inputs accounted for $6 \%$ of annual PNP in the central North Sea (IVb) where annual PNP was at a minimum (1960 to 2003 average $31 \mathrm{~g} \mathrm{C} \mathrm{m}^{-2} \mathrm{yr}^{-1}$ ), and was comparable to the contribution from rivers. However, in relative terms, deposition from the atmosphere was the major external source of nutrients to the northern North Sea and to stratified zones of the study area, representing more than twice the contribution from rivers.

\section{Role of denitrification}

Whilst inputs of nitrate from rivers and the atmosphere during the spring and summer productive period will lead to underestimation of PNP by our draw-down equations, there are other processes that lead to export of nitrogen from the water column and potential overestimation of PNP by our approach. The most important of these are denitrification and nitrous oxide production, both of which result in the venting of nitrogen to the atmosphere. Denitrification involves the microbial breakdown of organic matter in anoxic environments using nitrate, nitrite or nitrous oxide as the source of oxygen for respiration. Denitrification in sediments results in a net flux of nitrate from the water column into the pore waters and a release of nitrogen gas. Nitrous oxide production occurs in the water column and sediments as a by-product of the nitrification of ammonium ions to nitrate. Law \& Owens (1990) undertook studies to resolve the mass of inorganic nitrogen channelled through nitrification and denitrification in the North Sea, in both the water column and the major muddy sediment basins. Combining the 2 implied an annual flux to the atmosphere in the range of 9.5 to $17.7 \times$ $10^{7} \mathrm{~kg} \mathrm{~N} \mathrm{yr}^{-1}$, depending on details of the approach used to extrapolate the observations to the total area of the North Sea. Similar rates were estimated by Hydes et al. (1999) (and references therein). If we assumed that the flux estimated by Law \& Owens (1990) was uniformly distributed over the sea surface area of ICES Regions IVa, b and c combined, we get an annual flux of 12 to $22 \mathrm{mmol} \mathrm{N} \mathrm{m}^{-2} \mathrm{yr}^{-1}$. If we further assume that the rates are uniform over the year, then the export of nitrogen over the productive period (March-September) represents an overestimate of PNP equivalent to 7 to $13 \mathrm{mmol} \mathrm{N} \mathrm{m} \mathrm{yr}^{-1}$ or 0.6 to $1.0 \mathrm{~g} \mathrm{C} \mathrm{m}^{-2} \mathrm{yr}^{-1}$. Hence, it seems that the overestimation of PNP by our drawdown approach due to denitrification is probably small $(<5 \%)$ and roughly equivalent to the inputs to the system from atmospheric deposition.

\section{Influence of shelf edge exchange}

The major term missing from our estimates of regional PNP is the horizontal exchange with the northeast Atlantic across the $200 \mathrm{~m}$ isobath. As in our analysis of data from the ICES database (Fig. 9), Hydes et al. (2004) identified 2 ocean water types contributing to nitrate on the shelf. Beyond the shelf break to the southwest of the Celtic Sea $\left(48^{\circ}\right.$ to $52^{\circ} \mathrm{N}, 12^{\circ}$ to $\left.6^{\circ} \mathrm{W}\right)$, surface salinities $>35.4$ were associated with nitrate concentrations of 7 to $9 \mu \mathrm{M}$, whilst equivalent salinities from the Rockall Tough, offshore of the shelf break west of Scotland, were characterised by nitrate levels 
of approximately $11 \mu \mathrm{M}$. The coincidence of a peak in winter salinity on the outer shelf west of the UK and Ireland with a peak of PNP in Regions VII and VIa suggests that mixing of nutrients across the shelf edge may be a significant source of variability in shelf PNP. The volume exchanges close to the shelf edge are certainly large (Xing \& Davies 1999). However, the significance of these mixing rates will depend on the crossslope gradients of nitrate concentration. During the winter, differences in nitrate concentrations in the upper $200 \mathrm{~m}$ between the outer shelf and the ocean were approximately $3 \mu \mathrm{M}$ (see also Hydes et al. 2004). However, during June to September the difference was $<0.5 \mu \mathrm{M}$. Hence, we would expect a significant net mixing import of nitrate onto the shelf in the winter (which will already be reflected in winter nutrient concentrations on the shelf and hence included in our draw-down calculations), but perhaps a much smaller flux during the summer, assuming similar exchange rates. However, there is a possibility that significant fluxes may occur in the spring if phytoplankton blooms occurs earlier in shelf water than in the ocean, generating a cross-slope gradient of nitrate. Thus, quantifying cross-slope fluxes remains an area of uncertainty.

There is a variety of evidence for an exceptional encroachment of ocean water onto the European shelf during the early 1990s. Heath et al. (1991) have previously reported unusually high anomalies of salinity during this period, coinciding with a peak since 1865 in the NAO index characterized by enhanced westerly winds and oceanic transport. Edwards et al. (1999), Holliday \& Reid (2001), and Lindley et al. (1990) reported exceptional incidences of oceanic species in the plankton collected along European continental shelf routes by the continuous plankton recorder (CPR) during 1989 and 1997 to 1998, and changes in many aspects of the fisheries and marine ecology have been identified during this period, leading to it being referred to as a 'regime shift' (Reid et al. 2001a,b, Weijerman et al. 2005). In our study we can perhaps identify one of the processes underlying the so-called regime shift as being the injection of a significant mass of nitrate-nitrogen onto the shelf, which was then assimilated into the food web as new production. We can hypothesise that this nitrogen would be retained in the shelf waters and recycled through organic matter for a number of years subsequent to the nutrient injection, leading to a shift in food web productivity decaying slowly over time, due to denitrification and export of particulate matter from the shelf.

\section{Implications for higher trophic levels}

Heath (2005) estimated the annual productions in the North Sea of omnivorous and carnivorous zooplankton, macrobenthos carnivores, and the fish community, broken down into 4 feeding guilds, during the period 1973 to 1999. The mean production of the combined assemblage of zooplankton, benthos and fish was $45.4 \pm 10.7 \mathrm{~g} \mathrm{C} \mathrm{m}^{-2} \mathrm{yr}^{-1}$ (Table 6). Clearly, some elements of the food web are unaccounted for in this synthesis, for example bacteria, gelatinous zooplankton (approximately $1 \mathrm{~g} \mathrm{C} \mathrm{m}^{-2} \mathrm{yr}^{-1}$; Heath 2005), benthic detritivores (perhaps 2 to $3 \mathrm{gC} \mathrm{m}^{-2} \mathrm{yr}^{-1}$ ), birds and mammals (approximately $0.02 \mathrm{gC} \mathrm{m}^{-2} \mathrm{yr}^{-1}$; Bryant \&

Table 6. Annual production ( $\mathrm{g} \mathrm{C} \mathrm{m}^{-2} \mathrm{yr}^{-1}$ ) of secondary producers in the North Sea (Regions IVa, IVb and IVc combined) from Heath (2005), potential new primary production (PNP, $\mathrm{g} \mathrm{C} \mathrm{m}^{-2} \mathrm{yr}^{-1}$ ), and implied transfer efficiencies over the period $1973-1999$. The main species comprising the planktivorous fish guild were sprat Sprattus sprattus, herring Clupea harengus, sandeels Ammodytes sp. and Norway pout Trisopterus esmarkii. Benthivorous fish: plaice Pleuronectes platessa, lemon sole Microstomus kitt, and common dab Limanda limanda. Demersal piscivorous fish: cod Gadus morhua, haddock Melanogrammus aeglefinus, saithe Pollachius virens, and whiting Merlangius merlangus. Pelagic piscivorous fish: Atlantic mackerel Scomber scombrus, and horse mackerel Trachurus trachurus

\begin{tabular}{|c|c|c|c|c|}
\hline & $1973-1979$ & 1980-1989 & 1990-1999 & $1973-1999$ \\
\hline Omnivorous zooplankton & 35.72 & 33.8 & 36.62 & 35.34 \\
\hline Carnivorous zooplankton & 4.15 & 3.11 & 2.95 & 3.32 \\
\hline Macrobenthos carnivores & 1.10 & 1.24 & 1.49 & 1.30 \\
\hline Planktivorous fish & 3.85 & 3.65 & 3.73 & 3.73 \\
\hline Benthivorous fish & 0.31 & 0.35 & 0.32 & 0.33 \\
\hline Demersal piscivorous fish & 1.54 & 1.15 & 0.67 & 1.08 \\
\hline Pelagic piscivorous fish & 0.37 & 0.16 & 0.41 & 0.31 \\
\hline Total secondary producer assemblage & 47.04 & 43.47 & 46.21 & 45.41 \\
\hline Annual PNP & 47.75 & 52.91 & 50.00 & 50.49 \\
\hline Transfer efficiency: all secondary producers/PNP & 0.985 & 0.822 & 0.924 & 0.899 \\
\hline Transfer efficiency: omnivorous zooplankton/PNP & 0.748 & 0.639 & 0.732 & 0.700 \\
\hline Transfer efficiency: planktivorous fish/omnivorous zooplankton & 0.108 & 0.108 & 0.102 & 0.106 \\
\hline Transfer efficiency: all fish/PNP & 0.127 & 0.100 & 0.103 & 0.108 \\
\hline
\end{tabular}


Doyle 1992). We consider that these unaccounted-for components might represent a maximum of $10 \%$ of production by the combined assemblage. We have hypothesized (see 'Introduction') that the trophic transfer efficiency between new primary production and secondary producers (all higher trophic levels combined) should be approaching 1.0 in shelf seas, in contrast to the efficiency of total production transfer between trophic levels (0.1 to 0.2 ). Over the period 1973 to 1999, our results indicated that PNP in the North Sea (ICES Regions IVa, b and c combined) averaged $50.5 \pm 5.5 \mathrm{~g} \mathrm{C} \mathrm{m}^{-2} \mathrm{yr}^{-1}$, including the contribution of river inputs and atmospheric deposition, which was not significantly different from the estimated production of the combined secondary producers ( $t$-test, $\mathrm{p}<$ 0.01 ), and the mean ratio of secondary production: PNP was 0.90 (Table 6). Hence, we conclude that the various estimates of trophic level production are apparently consistent with our hypothesis regarding transfer efficiencies.

The time series of production by zooplankton and planktivorous fish in the North Sea were significantly and positively correlated $(\mathrm{r}=0.365, \mathrm{p}<0.05$, modified degrees of freedom $\mathrm{N}^{*}=20$ according to the MCM test; Heath 2005), indicating resource-driven, or bottom-up control at the guild level (Frank et al. 2006). Similarly, Frederiksen et al. (2006) showed that off the Scottish east coast in the northwestern North Sea, the food web connecting zooplankton through planktivorous fish (sandeels) to breeding success of seabirds, was also bottom-up controlled. Frank et al. (2007) found that, given the species richness of fish in the North Sea, these correlations were consistent with an emergent pattern of bottom-up vs. top-down control for shelf ecosystems around the North Atlantic in which species-rich, low-latitude systems tend to exhibit bottom-up control, while species-poor, highlatitude systems tend to exhibit top-down control. However, the correlation coefficient between the time series of PNP and combined production by zooplankton, macrobenthos and fish, though positive, was not significant according to the MCM test (Fig. 14). Correlation coefficients between the time series of PNP and both zooplankton and planktivorous fish production were negative, though also insignificant according to the MCM test in both cases. It is not clear whether or not we should take this as evidence of a lack of bottomup control between PNP and zooplankton, and that grazing by zooplankton may be a significant top-down control. If this were the case, grazing could control the extent of utilization of nitrate from the water column and we should conclude that inter-annual variability in zooplankton production is not primarily determined by food abundance. In contrast, a meta-analysis of correlations between zooplankton abundance and the CPR

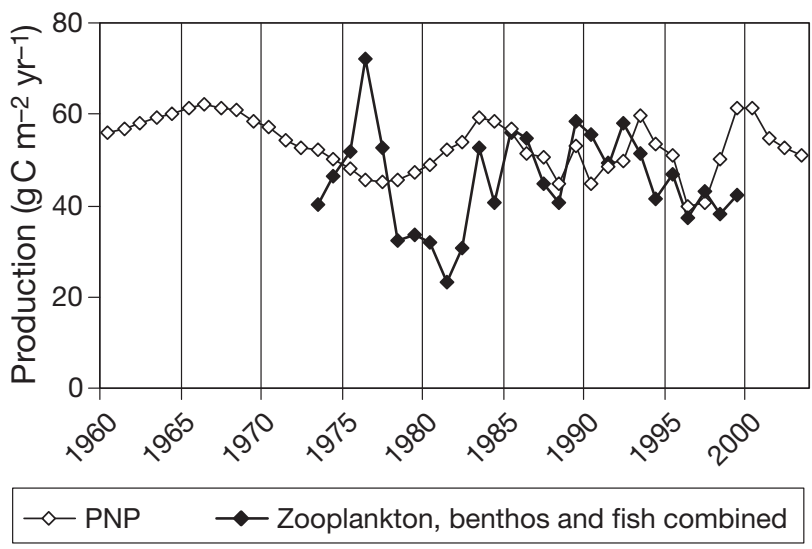

Fig. 14. North Sea (Regions IVa, IVb and IVc combined) potential new primary production (PNP, open symbols) compared to the combined annual productions of omnivorous and carnivorous zooplankton, carnivorous macrobenthos and fish in the North Sea (filled symbols; Heath 2005)

colour index (indicative of phytoplankton abundance) showed widespread positive correlations in the NE Atlantic region, which were interpreted as indicating bottom-up control (Richardson \& Schoeman 2004). Clearly the issue of trophic control is a priority for further research and is very important for assessing the sensitivity of marine food webs to harvesting and climate change. For example, there might be a case for managing fisheries harvesting more conservatively in areas and periods of low annual PNP in order to minimize detrimental effects on the food web. Our timeseries estimates of PNP based on nutrient utilization should provide a strong basis for modelling studies to examine such an issue.

Acknowledgements. This work was carried out under projects MF0754 and MF0758 funded by the Scottish Government Marine Directorate and an Exploratory Research award to D.J.B. from the Joint Research Centre (JRC), Ispra. HAMSOM outputs were produced by Kai Logemann as part of the EU-STEREO project (FAIR-CT98-412).

\section{LITERATURE CITED}

Backhaus JO, Hainbucher D (1987) A finite difference general circulation model for shelf seas and its application to low frequency variability on the North European Shelf. In: Nihoul JC, Jamart BM (eds) Three-dimensional models of marine and estuarine dynamics. Elsevier Oceanogr Ser 45. Elsevier Science, New York, p 221-244

Behrenfeld MJ, Falkowski PG (1997) Photosynthetic rates derived from satellite-based chlorophyll concentration. Limnol Oceanogr 42:1-20

Bisagni JJ (2003) Seasonal variability of nitrate supply and potential new primary production in the Gulf of Maine and Georges Bank regions. J Geophys Res 108(C11):8015 doi:10.1029/2001JC001136

> Boulart C, Flament P, Gentilhomme V, Deboudt K and others (2006) Atmospherically-promoted photosynthetic activity 
in a well-mixed ecosystem: significance of wet deposition events of nitrogen compounds. Estuar Coast Shelf Sci 69:449-458

Bryant AD, Doyle P (1992) Static predation loading estimation for North Sea top predators. ERSEM Prog Rep Jan 1992, Annex 6:1-16 (EU MAST I project CT90-0021). Netherlands Institute for Sea Research, Den Burg, Texel

Charnock H, Dyer KJ, Huthnance JM, Liss PS, Simpson JH, Tett PB (1994) Understanding the North Sea system. Chapman \& Hall, London

Chassot E, Mélin F, Le Pape O, Gascuel D (2007) Bottom-up control regulates fisheries production at the scale of ecoregions in European seas. Mar Ecol Prog Ser 343:45-55

Cleveland WS, Grosse E, Shyu WM (1992) Local regression models. In: Chambers JM, Hastie TJ (eds) Statistical models, Cole Advanced Books \& Software, Pacific Grove, CA, p 309-376

Dugdale RC, Goering JJ (1967) Uptake of new and regenerated forms of nitrogen in primary productivity. Limnol Oceanogr 12:196-206

Edwards M, John AWG, Hunt HG, Lindley JA (1999) Exceptional influx of oceanic species into the North Sea late 1997. J Mar Biol Assoc UK 79:737-739

Eppley RW, Peterson BJ (1979) Particulate organic matter flux and planktonic new production in the deep ocean. Nature 282:677-680

Frank KT, Petrie B, Shackell NL, Choi JS (2006) Reconciling differences in trophic control in mid-latitude marine ecosystems. Ecol Lett 9:1096-1105

Frank KT, Petrie B, Shackell NL (2007) The ups and downs of trophic control in continental shelf ecosystems. Trends Ecol Evol 22(5):236-242

Franks PJS, Chen C (1996) Plankton production in tidal fronts: a model of Georges Bank in summer. J Mar Res 54: 631-651

Frederiksen M, Edwards M, Richardson AJ, Halliday NC, Wanless S (2006) From plankton to top predators: bottomup control of a marine food web across four trophic levels. J Anim Ecol 75:1259-1268

Goes JI, Saino T, Oaku H, Ishizaka J, Wong CS, Nojiri Y (2000) Basin scale estimates of sea surface nitrate and new production from remotely sensed seas surface temperature and chlorophyll. Geophys Res Lett 27:1263-1266

Hastie T, Tibshirani R (1990) Generalized additive models. Chapman \& Hall, London

Heath MR (2005) Changes in the structure and function of the North Sea fish food web, 1973-2000, and the impacts of fishing and climate. ICES J Mar Sci 62:847-868

Heath MR (2007) Spatially resolved monthly riverine fluxes of oxidised nitrogen (nitrate and nitrite) to the European shelf seas, 1960-2005. FRS Internal Report 02/07. Available at: www.frs-scotland.gov.uk/FRS.Web/Uploads/ Documents/0207.pdf. Accessed 17 October 2007

Heath MR, Henderson EW, Slesser G, Woodward EMS (1991) High salinity in the North Sea. Nature 352:116

Holliday P, Reid PC (2001) Is there a connection between high transport of water through the Rockall Trough and ecological changes in the North Sea? ICES J Mar Sci 58:270-274

Horne EPW, Loder JW, Harrison WG, Mohn R, Lewis MR, Irwin B, Platt T (1989) Nitrate supply and demand at the Georges Bank tidal front. Sci Mar 53:145-158

Hurrell JW, Kushnir Y, Visbeck M, Ottersen G (2003) An overview of the North Atlantic Oscillation. In: Hurrell JW, Kushnir Y, Ottersen G, Visbeck M (eds) The North Atlantic Oscillation: climate significance and environmental impact. Geophys Monogr Ser 134:1-35

Hydes DJ, Kelly-Gerreyn BA, Le Gall AC, Proctor R (1999)
The balance of supply of nutrients and demands of biological production and denitrification in a temperate latitude shelf sea - a treatment of the southern North Sea as an extended estuary. Mar Chem 68:117-131

> Hydes DJ, Gowen RJ, Holliday NP, Shammon T, Mills D (2004) External and internal control of winter concentrations of nutrients (N, P and $\mathrm{Si}$ ) in north-west European shelf seas. Estuar Coast Shelf Sci 59:151-161

Jennings JC, Gordon LI, Nelson DM (1984) Nutrient depletion indicates high primary productivity in the Weddell Sea. Nature 309:51-54

Law CS, Owens NJP (1990) Denitrification and nitrous oxide in the North Sea. Neth J Sea Res 25:65-74

Laws EA, Falkowski PG, Smith WO Jr, Ducklow H, McCarthy JJ (2000) Temperature effects on export production in the open ocean. Global Biogeochem Cycles 14:1231-1246

Le Fevre J (1986) Aspects of the biology of frontal systems. Adv Mar Biol 23:163-299

Lenhart HJ, Radach G, Ruardij P (1997) The effects of river input on the ecosystem dynamics in the continental coastal zone of the North Sea using ERSEM. J Sea Res 38:249-274

Lindley JA, Roskell J, Warner AJ, Halliday NC, Hunt HG, John AWG, Jonas TD (1990) Doliolids in the German Bight in 1989: evidence for exceptional inflow into the North Sea. J Mar Biol Assoc UK 70:679-682

Moll A (1997) Modelling primary production in the North Sea. Oceanography 10:24-26

OSPAR (1998) Principles of the Comprehensive Study on Riverine Inputs and Direct Discharges (RID). OSPAR Report 1985, Vol 5. Available at: www.ospar.org/ documents/dbase/decrecs/agreements/98-05e_RID\%20 principles.doc. Accessed 17 October 2007

> Pauly D, Christensen V (1995) Primary production required to sustain global fisheries. Nature 374:255-257

Pyper BJ, Peterman RM (1998) Comparison of methods to account for autocorrelation in correlation analyses of fish data. Can J Fish Aquat Sci 55:2127-2140

R Development Core Team (2005) R: a language and environment for statistical computing. R Foundation for Statistical Computing, Vienna. Also available at: www.R-project.org.

Radach G, Gekeler J (1996) Annual cycles of horizontal distributions of temperature and salinity, and of concentrations of nutrients, suspended particulate matter and chlorophyll on the northwest European shelf. Dtsch Hydrogr Z 48: 261-297

Radach G, Moll A (2006) Review of 3-dimensional ecological modelling related to the North Sea shelf system. Part 2. Model validation and data needs. Oceanogr Mar Biol Ann Rev 44:1-60

Radach G, Pätsch J (2007) Variability of continental riverine freshwater and nutrient inputs into the North Sea for the years 1977-2000 and its consequences for the assessment of eutrophication. Estuar Coasts 30:66-81

Redfield AC, Ketchum BH, Pritchard FA (1963) The influence of organisms on the composition of seawater. In: Hill $\mathrm{N}$ (ed) The sea, Vol 2. Interscience, New York

Rees AP, Owens NJP, Heath MR, Plummer DH, Bellerby RS (1995) Seasonal nitrogen assimilation and carbon fixation in a fjordic sea loch. J Plankton Res 17:1307-1324

> Reid PC, De Borges MF, Svendsen E (2001a) A regime shift in the North Sea circa 1988 linked to changes in the North Sea horse mackerel fishery. Fish Res 50:163-171

> Reid PC, Holliday NP, Smyth TJ (2001b) Pulses in the eastern margin current and warmer water off the north west European shelf linked to North Sea ecosystem changes. Mar Ecol Prog Ser 215:283-287 
Richardson K, Pedersen B (1998) Estimation of new production in the North Sea: consequences for temporal and spatial variability in phytoplankton. ICES J Mar Sci 55: $574-580$

Richardson AJ, Schoeman DS (2004) Climate impact on plankton ecosystems in the northeast Atlantic. Science 305:1609-1612

Richardson K, Visser AW, Pedersen FB (2000) Subsurface phytoplankton blooms fuel pelagic production in the North Sea. J Plankton Res 22:1663-1671

Sathyendranath S, Cota G, Stuart V, Maass H, Platt T (2001) Remote sensing of phytoplankton pigments: a comparison of empirical and theoretical approaches. Int J Remote Sens 22:249-273

Simpson HJ, Hunter JR (1974) Fronts in the Irish Sea. Nature 250:404-406

Steele JH (1974) The structure of marine ecosystems. Blackwell, Oxford

Editorial responsibility: Andrew Brierley,

St. Andrews, UK
Tarrasón L (2003) Transboundary acidification, eutrophication and ground level ozone in Europe. EMEP Status Report 1/2003. Part II. Unified EMEP Model Performance. Norwegian Meteorological Institute, Oslo

Vitousek PM, Howarth RJ (1991) Nitrogen limitation on land and in the sea: How can it occur? Biogeochem 13:87-115

- Weijerman M, Lindeboom H, Zuur AF (2005) Regime shifts in marine ecosystems of the North Sea and Wadden Sea. Mar Ecol Prog Ser 298:21-39

Weston K, Fernand L, Mills DK, Delahunty R, Brown J (2005) Primary production in the deep chlorophyll maximum of the central North Sea. J Plankton Res 27:909-922

Xing J, Davies AM (1999) Processes influencing the circulation and bottom mixing across the shelf slope: the importance of the slope topography and the coast. J Mar Syst 21:341-377

Yool A, Martin AP, Fernández C, Clark DR (2007) The significance of nitrification for oceanic new production. Nature 447:999-1002

Submitted: October 18, 2007; Accepted: February 25, 2008 Proofs received from author(s): June 27, 2008 